\title{
Review
}

\section{Cellular and molecular mechanisms involved in the neurotoxicity of opioid and psychostimulant drugs}

\author{
Teresa Cunha-Oliveira, Ana Cristina Rego, Catarina R. Oliveira* \\ Center for Neuroscience and Cell Biology and Institute of Biochemistry, Faculty of Medicine, University of Coimbra, \\ 3004-504 Coimbra, Portugal
}

\section{A R T I C L E I N F O}

\section{Article history:}

Accepted 18 March 2008

Available online 27 March 2008

Keywords:

Drug of abuse

Neurotoxicity

Apoptosis

Oxidative stress

Glutamate

Dopamine

Cocaine

Heroin

Amphetamine

\begin{abstract}
A B S T R A C T
Substance abuse and addiction are the most costly of all the neuropsychiatric disorders. In the last decades, much progress has been achieved in understanding the effects of the drugs of abuse in the brain. However, efficient treatments that prevent relapse have not been developed. Drug addiction is now considered a brain disease, because the abuse of drugs affects several brain functions. Neurological impairments observed in drug addicts may reflect drug-induced neuronal dysfunction and neurotoxicity. The drugs of abuse directly or indirectly affect neurotransmitter systems, particularly dopaminergic and glutamatergic neurons. This review explores the literature reporting cellular and molecular alterations reflecting the cytotoxicity induced by amphetamines, cocaine and opiates in neuronal systems. The neurotoxic effects of drugs of abuse are often associated with oxidative stress, mitochondrial dysfunction, apoptosis and inhibition of neurogenesis, among other mechanisms. Understanding the mechanisms that underlie brain dysfunction observed in drug-addicted individuals may contribute to improve the treatment of drug addiction, which may have social and economic consequences.
\end{abstract}

(c) 2008 Elsevier B.V. All rights reserved.

\section{Contents}

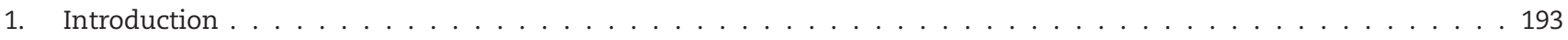

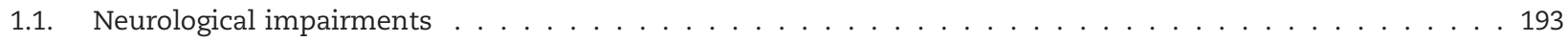

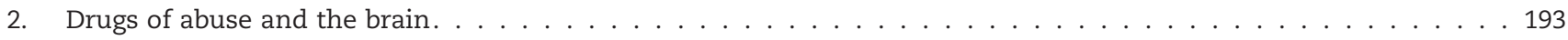

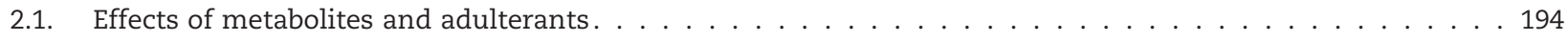

2.2. Short-term neurochemical effects . . . . . . . . . . . . . . . . . . . . . . . . . . . 195

2.3. Long-term neurochemical effects . . . . . . . . . . . . . . . . . . . . . . . . . . . . . . . 196

2.3.1. Glutamate and neuroplasticity — implications for the toxicity of drugs of abuse . . . . . . . . . . 196

2.4. Intracellular mechanisms of neurotoxicity induced by amphetamines, cocaine or heroin. . . . . . . . . . . 197

2.4.1. Oxidative stress caused by dopamine and drugs of abuse . . . . . . . . . . . . . . . . . . 197

2.4.2. Cell death by apoptosis caused by drugs of abuse . . . . . . . . . . . . . . . . . . . 200

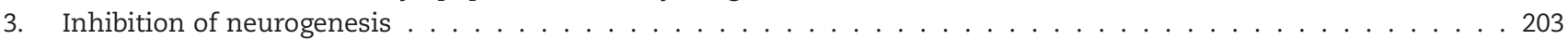

\footnotetext{
* Corresponding author. Fax: +351 239822776.

E-mail address: catarina@cnc.cj.uc.pt (C.R. Oliveira).

URL: http://www.cnbc.pt/research/research01.asp?lg=2 (C.R. Oliveira)
} 
4. Conclusions. . . . . . . . . . . . . . . . . . . . . . . . . . . . 204

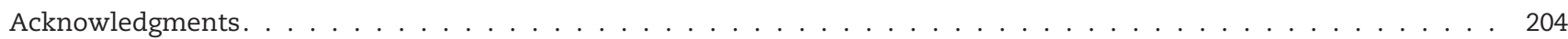

References . . . . . . . . . . . . . . . . . . . . . . . . . . . . . . 204

\section{Introduction}

Addictions are the most expensive of the neuropsychiatric disorders (Uhl and Grow, 2004) mainly due to the costs of health care, productivity loss and crime (United Nations Office on Drugs and Crime, 2007; Office of National Drug Control Policy, 2004).

Worldwide, the annual prevalence of illicit drug abuse is about $4.8 \%$ of the world population, but some countries present much higher prevalences (Table 1). In Europe, opiates are the most problematic drugs, being responsible for $60 \%$ of the treatment demands (European Monitoring Centre for Drugs and Drug Addiction, 2007).

Addiction is a chronic relapsing disease (Leshner, 1997), often accompanied by several neurological impairments such as deficits in cognition, motivation, insight and attention, behavioural disinhibition, emotional instability, depression, anhedonia, impulsiveness, aggressiveness and movement disorders (Majewska, 1996; Pau et al., 2002).

The main characteristic of drug addiction is the compulsive drug use despite serious negative consequences. Drugs become more important than other goals and all activities are directed towards obtaining and consuming the drugs (Hyman et al., 2006). The use of drugs leads to the desired psychoactive effect, but also leads to toxic side-effects and to drug dependence, followed by short-term and long-term health and social problems due to a reduction in life-sustaining activities. In this review, we describe the neurological impairments observed in amphetamine, cocaine and opiate abusers, correlating these impairments with the cellular and molecular effects of the drugs of abuse in the brain.

\subsection{Neurological impairments}

As previously noticed, drug abusers present several neurological impairments. Cocaine abusers may suffer from seizures (Koppel et al., 1996), cerebral ischaemia, cerebral hemorrhages, infarction, optic neuropathy, cerebral atrophy, cognitive impairment, and mood and movement disorders (Majewska,

Table 1 - Annual prevalence of drug abuse in Europe, USA and worldwide

Annual prevalence (\% of population)

\begin{tabular}{llrc} 
& Europe & USA & World \\
\hline Cannabis & 5.6 & 12.6 & 3.8 \\
Amphetamines & 0.5 & 1.8 & 0.6 \\
Opiates & 0.7 & 0.6 & 0.4 \\
Cocaine & 0.75 & 2.8 & 0.3 \\
Ecstasy & 0.6 & 1.0 & 0.2 \\
\hline
\end{tabular}

Source: World Drug Report, 2007 (http://www.unodc.org/pdf/research/ wdr07/WDR_2007.pdf).
1996). Brain lesions and cerebral atrophy are mainly observed in the prefrontal cortex and basal ganglia of human cocaine abusers (Bartzokis et al., 1996; Langendorf et al., 1996). Some authors defend that vasoconstriction and consequent hypoxia may be the primary cause of brain dysfunction induced by cocaine (Olsen, 1995). Importantly, prenatal brain toxicity constitutes a serious negative effect of cocaine (Nassogne et al., 1998).

Heroin neuropathology often involves hypoxic-ischaemic changes with cerebral edema, ischaemic neuronal damage and neuronal loss. These effects may be due to prolonged heroininduced respiratory depression and to infections (Buttner et al., 2000). Heroin abusers present cerebral atrophy (Wolf and Mikhael, 1979), demyelination (Lyoo et al., 2004), cerebral blood perfusion abnormalities (Rose et al., 1996), and decreased neuronal density in the globus pallidus (Pearson et al., 1976). Neuropathological changes in heroin abusers may also be caused by adulterants.

Comparative studies between chronic amphetamine and opiate drug users showed that these individuals displayed pronounced neuropsychological impairment in the domains of executive and memory functions. Upon several years of drug abstinence these impairments persisted, suggesting neuropathology in frontal and temporal cortices (Ersche et al., 2006). Post-mortem studies indicate that neuropathology in amphetamine users is more severe and more specific, when compared to opiate users. Brains of opiate users presented non-specific ventricular and cortical volume loss, whereas in the brains of psychostimulant users the prefrontal and medial temporal lobe areas were particularly affected (Ersche et al., 2006). Chronic drug abuse seems to be associated with altered monoamine activity, which may be responsible by some of the behavioural deficits observed in drug addicts (Rogers and Robbins, 2001).

\section{Drugs of abuse and the brain}

Drugs of abuse interact with the brain, affecting brain systems that respond to physiological stimuli such as food, water and social interaction, which are critical to survival. Imaging studies, using positron emission tomography (PET) and functional magnetic resonance imaging (fMRI), have implicated the involvement of different brain circuits in drug addiction (reviewed by Volkow et al., 2003). The interaction of the drugs with these circuits may be different in the different phases of drug addiction: intoxication, withdrawal, bingeing and craving (reviewed by Goldstein and Volkow, 2002).

The main brain circuits and structures implicated in the effects of the drugs are the ones that mediate reward (nucleus accumbens (NAc) and ventral pallidum), memory and learning (amygdala and hippocampus), motivation/drive (orbitofrontal cortex (OFC) and subcallosal cortex) and control (prefrontal 
cortex and anterior cingulate gyrus (CG)) (Volkow et al., 2003). In drug-addicted individuals, a loss of inhibitory control from the prefrontal cortex impairs the regulation of the activity of the other circuits, perpetuating the cycle of addiction.

Relapse to drug use is often precipitated by drug-associated cues, which activate cortical regions (such as the anterior cingulate cortex and the orbitofrontal cortex) and the insula, as determined by imaging studies (PET and fMRI) (Volkow et al., 2003). The function of the insula, which is involved in conscious emotional feelings, seems to be essential to mediate relapse (Naqvi et al., 2007).

The brain areas involved in the circuits affected by drug addiction are innervated by dopaminergic and glutamatergic projections, and modifications in these projections mediate many of the adaptations involved in drug addiction. Two dopaminergic brain pathways (the reward pathway and the nigrostriatal pathway) mediate many of the effects of the drugs of abuse. The reward pathway is acutely activated by all the drugs of abuse, and mediates the reinforcing effects of these drugs. This pathway consists in the projection of dopaminergic neurons in the ventral tegmental area (VTA) to several structures involved in emotions, thoughts, memories and planning and executing behaviours. One of these structures, implicated in the addictive effects of the drugs, is the NAc, in the ventral striatum. This structure is involved in reward and addiction, but also in motivation and learning (Di Chiara et al., 1999). Another brain structure receiving projections from VTA neurons is the prefrontal cortex, which coordinates executive functions. The nigrostriatal pathway is involved in motor and motivational aspects of behaviour (Gerfen, 1984) and is composed by dopaminergic neurons that project from the substantia nigra pars compacta to the caudate-putamen. Several drugs of abuse increase extraneuronal dopamine in dopaminergic nerve terminals in the striatum (Pereira et al., 2004, 2006a). Dopamine and excitatory amino acids were suggested to play an important role in the nigrostriatal dopaminergic damage induced by methamphetamine (Schmidt et al., 1985; Sonsalla et al., 1989). Interestingly, there is a marked difference in specificity between methamphetamine and MDMA regarding the neurotransmitter systems and, consequently, the brain areas affected by each of these compounds. Whereas methamphetamine preferentially affects dopaminergic brain areas, MDMA is more selective to serotonergic brain areas (reviewed by Green et al., 2003).

\subsection{Effects of metabolites and adulterants}

The effects of a given drug of abuse, including its toxicity, may be affected by compounds resulting from its metabolism, particularly when these compounds are able to cross the blood brain barrier (BBB). Cocaine metabolism gives rise to active compounds that cross the $\mathrm{BBB}$, namely benzoylecgonine, norcocaine and cocaethylene. Cocaethylene results from transesterification of cocaine and ethanol and is responsible by the synergistic effects of cocaine and ethanol on the brain (Bunney et al., 2001). Cocaine metabolism also originates inactive compounds, such as ecgonine methyl ester, ecgonine and methyl ecgonine, which were shown not to induce neurotoxicity in cortical neurons. However, in the same conditions, cocaine and norcocaine were neurotoxic (Nassogne et al., 1998). Since cocaine and nor- cocaine, in contrast to the non-toxic metabolites, are cationic amphiphiles, it has been suggested that the neurotoxicity induced by cocaine may require intracellular penetration of cocaine and trapping in an acidic intracellular compartment (Nassogne et al., 1998), since when positively charged it may accumulate in negatively charged compartments, such as mitochondria.

The metabolism of D-amphetamine produces the active compounds norephedrine, hydroxyamphetamine and hydroxynorephedrine (Jenkins and Cone, 1998), but the extent of $\mathrm{D}$-amphetamine metabolization is much lower, when compared with cocaine. In contrast, metabolism of the amphetamine derivative ecstasy (or 3,4-methylenedioxymethamphetamine, MDMA) seems to be important for its neurotoxicity. The catechol metabolite $\mathrm{N}$-methyl- $\alpha$-methyldopamine that results from O-demethylenation of MDMA and the catechol metabolites resulting from $\mathrm{N}$-demethylation followed by $\mathrm{O}$-demethylenation of MDMA, such as $\alpha$-methyldopamine and 6-hydroxy- $\alpha$-methyldopamine, were shown to be neurotoxic, and may be responsible by MDMA toxicity in catecholaminergic PC12 cells. In these cells, MDMA and its metabolites 3,4-methylenedioxyamphetamine (MDA) and 3-methoxy- $\alpha$-methyldopamine were shown to be less toxic (Milhazes et al., 2006). In cortical neurons, MDMA and its metabolites $N$-methyl- $\alpha$-methyldopamine and $\alpha$-methyldopamine were also shown to be neurotoxic (Capela et al., 2006a). Furthermore, thioether MDMA metabolites were demonstrated to be stronger neurotoxins in comparison with their parent catechols and MDMA, in cultures of rat cortical neurons (Capela et al., 2007b).

Heroin metabolism occurs readily upon self-administration, by the deacetylation to the active metabolites 6-monoacetyl morphine (6-MAM) and morphine. The formation of 6MAM may occur spontaneously in aqueous media. Hence, heroin may be considered as a pro-drug, because it does not have intrinsic activity, but, due to its high lipophilicity it facilitates the distribution of the active metabolites, 6-MAM and morphine (Sawynok, 1986). Since morphine can induce neurotoxicity (Hu et al., 2002; Mao et al., 2002; Lim et al., 2005), it may contribute to the neurotoxic effects of heroin. However, we showed that 6-MAM and morphine do not contribute to street heroin neurotoxicity in cultured cortical neurons (Cunha-Oliveira et al., 2007). In accordance, a recent study suggests that heroin has a higher neurotoxic potential in comparison with morphine (Tramullas et al., 2008).

Contaminants and adulterants may also be implicated in the effects and toxicity of the drugs. We have previously shown that street heroin with a purity of $27 \%$ was more toxic to PC12 cells than 62\% pure heroin (Oliveira et al., 2002). Moreover, the latter form of heroin induced a large activation of caspase-3 in rat cortical neurons, whereas $\sim 100 \%$ pure heroin hydrochloride only slightly activated this caspase (Cunha-Oliveira et al., 2007).

Another factor affecting the effects of the drugs is polyabuse. Interactions between molecules of different drugs, such as cocaine and morphine (Garrido et al., 2007) may lead to distinct effects when compared to the drugs alone.

In order to analyse the factors leading to the neurotoxicity of the drugs of abuse, upon acute or chronic exposure, it is important to understand the short-term and long-term neurochemical effects of these drugs. 


\subsection{Short-term neurochemical effects}

At the cellular level the drugs of abuse interfere with neurotransmitter systems by imitating (opiate drugs - endogenous opioids, nicotine - acetylcholine), stimulating (cocaine, amphetamines - dopamine, ecstasy - serotonin) or blocking (alcohol glutamate) the effects of the neurotransmitters (Hyman et al., 2006).

The stimulant drugs amphetamine and cocaine directly increase extraneuronal dopamine levels through different mechanisms (Fig. 1). Amphetamine induces an increase in extracellular monoamines, by interacting directly with monoaminergic cells (Fig. 1A). Although amphetamine has comparable effects in neurons containing serotonin, noradrenaline and dopamine, the effects implicated in its reinforcing properties are mainly mediated by dopamine (Fleckenstein et al., 2007). Furthermore, dopamine synthesis is important for methamphetamine toxicity in dopamine and serotonin systems (Schmidt et al., 1985).

Due to its structural similarity with dopamine, amphetamine is a substrate for the dopamine transporter (DAT) (Sitte et al., 1998). At low concentrations, amphetamine is transported by the DAT to the cytosol and increases the intracellular binding sites of the DAT for dopamine, resulting in the exchange of extracellular amphetamine by intracellular dopamine, and leading to an increase in extracellular dopamine (Jones et al., 1999). When present at higher extracellular concentrations, amphetamine may diffuse into the cell, due to its lipophilicity (Sulzer et al., 1995; Kahlig et al., 2005).

Intracellular amphetamine also induces reverse transport by the DAT because it contributes to increase the intracellular dopamine concentration. Methamphetamine interferes with the vesicular monoamine transporter 2 (VMAT-2) function, rapidly redistributing VMAT-2 to a non-vesicular location (Riddle et al., 2002), impairing the active transport of the monoamines into synaptic vesicles, where they are stored. In addition, amphetamine may enter in the vesicles by diffusion, due to its weak base properties (Sulzer et al., 2005, for review). Since amphetamine is a weak base, at acidic $\mathrm{pH}$ it accepts protons leading to alkalinization inside the vesicles. A low $\mathrm{pH}$ inside the vesicles is essential to maintain the proton gradient used by VMAT-2 for active transport of monoamines into the vesicles.

Therefore, amphetamine induces the release of vesicular dopamine to the cytosol and impairs the storage of dopamine in the vesicles. Cytosolic dopamine is then released to the extracellular space via reverse transport by the DAT. For more detailed explanation the reader is referred to the excellent review of Sulzer et al. (2005). The weak base effect explains mitochondrial dysfunction induced by amphetamine in the absence of dopamine, due to disruption of mitochondrial potential (Cunha-Oliveira et al., 2006a), which may lead to a decrease in intracellular ATP (Oliveira et al., 2002).

Amphetamine also interferes with dopamine synthesis. At low concentrations, amphetamine promotes dopamine synthesis (Kuczenski, 1975), whereas at higher concentrations or upon prolonged exposure, it leads to tyrosine hydroxylase (TH) inhibition (Ellison et al., 1978) or decreased TH protein levels (Bowyer et al., 1998). Amphetamine also impairs dopamine metabolism by inhibiting monoamine oxidase (MAO) (Ramsay and Hunter, 2002).
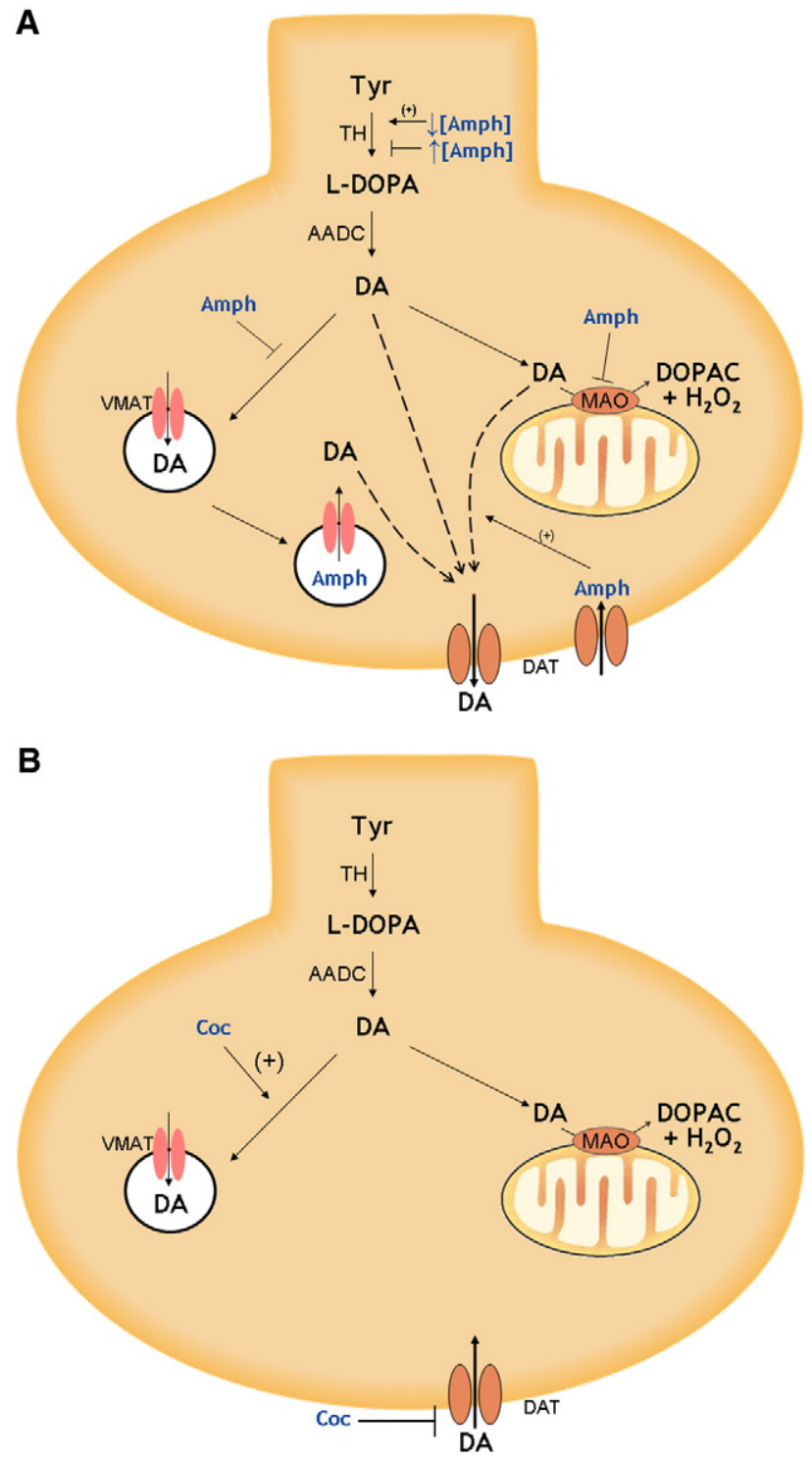

Fig. 1 - Direct effects of (A) amphetamine and (B) cocaine in dopaminergic nerve terminals. Both drugs increase extracellular dopamine accumulation by different mechanisms. In a simplified manner, amphetamine inhibits the storage of dopamine in synaptic vesicles, inducing an increase in cytosolic dopamine concentration and reversal of the DAT. Cocaine blocks the reuptake of dopamine by the DAT. For more detailed explanation see text. TYR - tyrosine, TH - tyrosine hydroxylase,

L-DOPA — L-dihydroxyphenylalanine, AADC - Aminoacid decarboxylase, Amph - amphetamine, Coc - cocaine, DAT - dopamine transporter, MAO - monoamine oxidase, VMAT - vesicular monoamine transporter, DOPAC - dihydroxyphenylacetic acid.

Amphetamine derivatives have common and distinct effects when compared with amphetamine. While no major differences are observed between amphetamine and methamphetamine effects (Sulzer et al., 2005), despite a subtly greater dopamine release induced by amphetamine in the prefrontal cortex (Shoblock et al., 2003), MDMA has an enhanced potency 
for 5-HT release and reduced potency for dopamine release, when compared to amphetamine and methamphetamine (Rothman and Baumann, 2003). MDMA is also an agonist of $5-\mathrm{HT}_{2 \mathrm{~A}}$ receptors (Nash et al., 1994), and MDMA neurotoxicity is often associated with depletion of serotonergic terminal markers (reviewed by Green et al., 2003). However, whereas MDMA is a serotonin neurotoxin in non-human primates and rats, it is a dopaminergic neurotoxin in the mouse (Logan et al., 1988). Differences in MDMA effects among animal species were previously reviewed by Green et al. (2003).

Cocaine inhibits the DAT (Brown et al., 2001), preventing the reuptake of dopamine into the nerve terminal (Fig. 1B). The inhibition of the DAT results in increased levels of dopamine in the synaptic cleft. Cocaine also inhibits the monoamine transporters noradrenaline transporter (NET) and serotonin transporter (SERT) (Gatley et al., 1998). However, as it happens with amphetamine, reinforcing effects of cocaine are largely dependent on its effect in dopaminergic neurotransmission (Ritz et al., 1987).

Cocaine also interacts with the VMAT-2 (Fig. 1B), favoring the storage of catecholamines inside synaptic vesicles (Brown et al., 2001). It was suggested that cocaine-induced inhibition of the DAT and increased vesicular sequestration of dopamine, causes a shift in the ratio of cytoplasmic to vesicular dopamine, increasing the amount of neurotransmitter packaged in each vesicle before its release. This effect on the VMAT-2 would contribute to a further increase in synaptic dopamine, upon a depolarizing stimulus (Brown et al., 2001).

Interestingly, cocaine metabolite cocaethylene is a more selective indirect dopamine agonist than cocaine, with relatively weak potency at the SERT (Jatlow et al., 1996).

In contrast with the stimulant drugs, opiates induce an increase in dopamine in the NAc by an indirect mechanism. The major targets of opiates are the opioid receptors, which mediate the endogenous effects of the opioid neuropeptides. Due to structural similarities with the opioid peptides, opiate drugs of abuse bind to $\mu$-opioid receptors present in gamma aminobutyric acid (GABA)-releasing interneurons in the VTA, inhibiting the release of GABA, an inhibitory neurotransmitter that acts on dopaminergic neurons to inhibit dopamine release. Thus, the action of the opiate drugs in the GABAergic interneurons results in an increase in dopamine release by the dopaminergic neurons of the VTA (Nestler, 2004b), which has been associated with reward mechanisms.

\subsection{Long-term neurochemical effects}

Chronic exposure of neurons to drugs of abuse results in longlasting alterations in neuronal physiology, leading to the development of drug addiction. For example, in chronic drug abusers, withdrawal induces a marked decrease in dopamine function in the brain (Volkow et al., 2004).

Adaptations to the drugs are in the basis for the development of sensitization or tolerance, in which the response to the same dose of a drug is increased or decreased, respectively. These processes are responsible for the withdrawal symptoms and increased motivation to drug abuse (Nestler, 2004a). These adaptations may be related to long-lasting changes in gene expression, as observed in chronic drug users, and some of these changes may be correlated with the development of the compulsive behaviour associated with drug addiction (Rhodes and Crabbe, 2005, for review).

Opiates have the most evident addictive effects, involving tolerance, withdrawal and a high rate of relapse. These effects may be explained by activation of intracellular signaling pathways that regulate gene expression, upon binding of opioids to their receptors.

One of the best characterized neuroadaptations induced by opioid drugs is the upregulation of the cAMP pathway that occurs in neurons from the locus coeruleus (reviewed by Nestler, 2004b) and NAc (Chieng and Williams, 1998). The molecular mechanisms involved in the upregulation of cAMP pathway seem to be partially mediated by the transcription factor CREB. Chronic opiate exposure induces CREB expression and activity, which is thought to mediate the expression of some of the components of the CAMP pathway. Cocaine and amphetamine also induce CREB activation due to an increase in the stimulation of dopamine (D1) receptors (Hyman et al., 2006, for review). CREB has many target genes, such as c-Fos, corticotropin-releasing factor (CRF), TH, brain derived neurotrophic factor (BDNF), adenylyl cyclase (isoform VIIII), enkephalins and dynorphin (Carlezon et al., 2005). The upregulation of dynorphin seems to mediate the decrease in the rewarding properties of the drugs, mediated by CREB (Cole et al., 1995). Dynorphin acts on k-opioid receptors present on VTA neurons to decrease dopamine release and represents a negativefeedback loop. Upregulation of cAMP pathway by the opiates leads to decreased dopamine release in the VTA when opiates are present. When opiates are no longer present, the decrease in dopamine release mediated by dynorphin may contribute to anhedonia and dysphoria that characterize the early phases of opiate withdrawal (Hyman et al., 2006, for review).

Changes in gene expression induced by chronic drug exposure may also underlie changes in the cellular responses to cytotoxic stimuli. In accordance, we observed that chronic exposure of PC12 cells to cocaine, amphetamine (CunhaOliveira et al., 2006c) and street heroin (Cunha-Oliveira et al., 2006b) involves adaptations to oxidative stress.

\subsubsection{Glutamate and neuroplasticity - implications for the} toxicity of drugs of abuse

Many evidences suggest the involvement of glutamatergic neurotransmission in the mechanisms of drug dependence involving the dopaminergic reward circuit in the brain (Tzschentke and Schmidt, 2003). On the other hand, an increase in extracellular glutamate has been associated with excitotoxic processes, due to increased activation of NMDA receptors and subsequent increase in intracellular $\mathrm{Ca}^{2+}$ concentration (for review, Rego and Oliveira, 2003).

Cocaine (You et al., 2007; Williams and Steketee, 2004; Kalivas and Duffy, 1998; Reid et al., 1997) and amphetamine (Anderzhanova et al., 2002; Reid et al., 1997; Abekawa et al., 1994; Wolf and Xue, 1999) increase extracellular glutamate concentrations in brain areas such as the VTA, NAc, prefrontal cortex or striatum.

Moreover, amphetamine toxicity and behavioural effects were previously shown to be attenuated by the NMDA receptor antagonist dizocilpine maleate (MK801) (Derlet et al., 1990), suggesting that amphetamine enhances the activity of NMDA receptors (Sonsalla, 1995). Furthermore, plasticity of 
glutamatergic synaptic transmission in the VTA is one of the brain adaptations induced by cocaine, and contributes to the development of addictive behaviours (Schilstrom et al., 2006; Wolf, 1998). Changes in the expression of NMDA receptor subunits were observed in the brains of cocaine-exposed rats (Huber et al., 2001; Schilstrom et al., 2006;Yamaguchi et al., 2002; Scheggi et al., 2002). In VTA neurons, cocaine induced an increase in NR1 and NR2B subunit expression and their redistribution to synaptic membranes (Schilstrom et al., 2006). NR2B expression was also shown to be increased in the NAc and in the hippocampus of cocaine-exposed rats. This effect was prevented in rats exposed to cocaine and MK-801 (Scheggi et al., 2002). Cocaine-induced changes in the expression of NMDA receptor subunits may be mediated by extracellular dopamine, via stimulation of dopamine receptors (Schilstrom et al., 2006). Interactions between NR2B subunits of the NMDA receptor and the D2 dopamine receptor were observed in the neostriatum of cocaine-exposed rats (Liu et al., 2006) and may contribute to the stimulant effect of cocaine.

Glutamatergic neurotransmission involving the NMDA receptor contributes to opiate dependence in humans (Bisaga et al., 2001). Ionotropic glutamate receptors in the VTA modulate opiate reinforcement (Xi and Stein, 2002). Moreover, NMDA receptor antagonists inhibit the development of physical dependence and tolerance (Trujillo, 2000). The NMDA receptor antagonists memantine (Ribeiro Do Couto et al., 2004) and MK801 (Tzschentke and Schmidt, 1995) are capable of preventing the acquisition of morphine-induced conditioned place-preference, suggesting that the glutamatergic system can modulate opiate reward. Moreover, the NMDA receptor antagonist MK-801 was shown to specifically block morphine-induced tolerance and neuronal apoptosis in the spinal cord (Mao et al., 2002).

Morphine dependence reduces the affinity of glycine for NMDA receptors in the NAc (Siggins et al., 2003; Martin et al., 2004). Moreover, morphine-dependent rats show decreased NR1 and NR2A subunit expression in the frontal cortex and hippocampus and increased levels of NR1 and NR2A in the NAc, whereas NR2B is not affected (Murray et al., 2007). These data suggest that NR2A-containing NMDA receptors in the NAc probably contribute to the development of opiate dependence. Another study also suggested that chronic morphine induces an increase in NR2A subunit function in the NAc, and a decrease in the function of the NMDA receptor subunits NR2B and 2C, which could result in altered excitability and integrative properties (Martin et al., 2004).

However, other authors showed that chronic morphine significantly increased the protein levels of NR1 and NR2B subunits in the NAc (Bajo et al., 2006). It was recently suggested that NR2B subunit-containing NMDA receptors may be involved in the rewarding effect of morphine (Kato et al., 2007; Ma et al., 2007). NR2B-containing NMDA receptors in the NAc and the dorsal hippocampus were proposed to play a significant role in mediating the reinstatement of rewarding responses to morphine (Ma et al., 2007). This effect seems to be specific for morphine because NR2B containing NMDA receptors are more involved in morphine reward rather than in natural rewards (Ma et al., 2006). Nevertheless, the acute exposure to opiates may have different effects on NMDA receptors when compared to the chronic exposure.
Changes in the composition of NMDA receptors may increase the susceptibility of cells to drug toxicity. We have previously observed that NR1/NR2B transfected HEK293 cells were more susceptible to acute street heroin toxicity when compared to NR1/NR2A and NR1 transfected cells. Street heroin toxicity was abolished by pre-incubation with MK-801 in NR1/NR2B expressing cells, suggesting the involvement of these NMDA receptor subunits in street heroin toxicity (Domingues et al., 2006).

\subsection{Intracellular mechanisms of neurotoxicity induced by amphetamines, cocaine or heroin}

Since addiction may be considered a brain disease (Leshner, 1997), neurotoxicity may underlie some of the effects of the drugs. The Interagency Committee on Neurotoxicology defined neurotoxicity as a broad concept, including any adverse effect on the structure or function of the central and/or peripheral nervous system by a biological, chemical or physical agent. In this definition, neurotoxic effects may be permanent or reversible and result from direct or indirect actions on the nervous system (Erinoff, 1995).

The brain is particularly sensitive to toxicity, because it is one of the most metabolically active tissues. A continuous supply of glucose is essential for the energy-consuming neuronal functions such as axonal transport or synaptic transmission. Although new neurons may be formed by neurogenesis in the adult brain (Gage, 2002), the existing neurons do not divide and thus dysfunction or death of these cells may result in irreversible damage. Furthermore, the brain is highly sensitive to oxidative stress due to its high content in polyunsaturated fatty acids, low levels of antioxidants, the presence of transition metals and high levels of oxygen consumption.

As previously discussed, drugs of abuse compromise important brain functions, what may in part result from their neurotoxicity. However, the neurotoxic effects of the drugs of abuse may be enhanced by environmental factors, such as elevated temperature and loud noise (Gesi et al., 2004; Capela et al., 2006b). In contrast, stress manipulations (e.g. restraint stress) protect mice against dopaminergic toxicity induced by repeated MDMA treatment (Johnson et al., 2004). Thus, environmental factors may determine the extent of the neurotoxic damage produced by the drugs of abuse.

Neurotoxicity induced by the drugs of abuse may be evaluated by several parameters. Herein we report the intracellular mechanisms of neurotoxicity of amphetamine, amphetamine derivatives, cocaine and heroin, associated with mitochondrial dysfunction, and oxidative stress, which may lead to cell death by apoptosis. However, other functional and morphological hallmarks of neurotoxicity induced by psychostimulant drugs of abuse have been described, such as changes in protein degradation (involving inhibition of the proteosome and autophagy) and resulting in the appearance of neuronal inclusions (Iacovelli et al., 2006, for review).

\subsubsection{Oxidative stress caused by dopamine and drugs of abuse}

2.4.1.1. Dopamine and oxidative stress. As described in the previous sections, virtually all of the drugs of abuse induce an increase in extracellular monoamines in specific regions of 
the brain. Accordingly, the neurotoxicity of methamphetamine is mainly observed in monoaminergic brain areas, particularly in dopaminergic nerve terminals in the striatum (Gibb and Kogan, 1979). Moreover, dopamine has been shown to be neurotoxic in vitro (Graham et al., 1978; McLaughlin et al., 1998) and in vivo (Hastings et al., 1996). Dopamine is easily oxidized, by enzymatic and non-enzymatic mechanisms, and may induce oxidative stress in dopaminergic and neighboring cells. This may contribute to the neurotoxicity of the drugs of abuse.

Synaptic activity of dopamine is mainly regulated by two mechanisms: reuptake, responsible for $70-80 \%$ of dopamine recycling, and/or inactivation (metabolism) (Amara and Kuhar, 1993). Dopamine may be metabolized intracellularly by MAO, a mitochondrial enzyme, present in the cytoplasmic side of the outer membrane. MAO catalyses the deamination of dopamine producing 3,4-dihydroxyphenylacetic acid (DOPAC) and hydrogen peroxide $\left(\mathrm{H}_{2} \mathrm{O}_{2}\right)$. Dopamine autooxidation produces the superoxide anion $\left(\mathrm{O}_{2} \cdot{ }^{-}\right)$and $\mathrm{H}_{2} \mathrm{O}_{2}$, which may react with transition metal ions, via the HaberWeiss/Fenton reactions, originating the highly toxic hydroxyl radical $(. \mathrm{OH})$. Furthermore, $\mathrm{O}_{2} \cdot{ }^{-}$reacts with nitric oxide, forming the highly toxic peroxinitrite (Cadet and Brannock, 1998). Thus, dopamine is both a neurotransmitter and a neurotoxin, and changes in dopamine metabolism may induce oxidative stress and cell death in dopaminergic or surrounding cells (Jones et al., 2000) if the antioxidant systems are not able to deal with the increase in the levels of ROS. An increase in ROS levels may lead to cell death due to the oxidation of important cellular macromolecules such as amino acids, phospholipids and nucleic acids (Cadet and Brannock, 1998).

The main antioxidant enzymes involved in $\mathrm{H}_{2} \mathrm{O}_{2}$ inactivation are glutathione peroxidase (GPx) and catalase (present in the peroxisomes). Superoxide dismutase (SOD), another antioxidant enzyme, may contribute to increase $\mathrm{H}_{2} \mathrm{O}_{2}$ levels by detoxification of $\mathrm{O}_{2}{ }^{-}$. The levels and the activity of these enzymes are regulated by the cells and are important to maintain cellular homeostasis. Therefore, the effects of chronic exposure to oxidants contrast with the effects of acute exposure. For example, acute exposure to $\mathrm{H}_{2} \mathrm{O}_{2}$ induces apoptotic cell death (Benedi et al., 2004; Jang and Surh, 2004), whereas chronic exposure to low concentrations of $\mathrm{H}_{2} \mathrm{O}_{2}$ induces cellular resistance to the acute toxicity of this compound (Wiese et al., 1995; Davies, 1999). Acute exposure to $\mathrm{H}_{2} \mathrm{O}_{2}$ may then be used as a model of cytotoxicity whereas chronic treatment with a low concentration of $\mathrm{H}_{2} \mathrm{O}_{2}$ may be a model of cell adaptation (Jackson et al., 1994).

Evidences of oxidative stress induced by amphetamine, amphetamine derivatives, cocaine and opiates are discussed in the following sections.

2.4.1.2. Amphetamines and oxidative stress. Exposure to amphetamine or amphetamine derivatives has been shown to induce oxidative stress in the nervous system (Table 2), and this was the subject of previous reviews (Yamamoto and Bankson, 2005;Cadet et al., 2007). Methamphetamine and D-amphetamine have been shown to increase ROS levels upon in vitro (Wu et al., 2007; Pubill et al., 2005) or in vivo (Frey et al., 2006a; Jimenez et al., 2004) exposure and the toxic effects of these drugs may be prevented by antioxidants. Moreover, in methamphetamine human abusers the activity of antioxidant enzymes was affected in several regions of the brain (Mirecki et al., 2004). In animal models, methamphetamine (Acikgoz et al., 2000) and D-amphetamine (Frey et al., 2006b; Carvalho et al., 2001) also affected the activity of antioxidant enzymes. In addition, evidences of oxidative damage have been reported in the brains of metamphetamine human abusers (Fitzmaurice et al., 2006) and methamphetamine (Acikgoz et al., 2000) or D-amphetamine (Frey et al., 2006a) exposed animals. In catecholaminergic cell cultures, we have previously shown that chronic exposure to $\mathrm{D}$-amphetamine induces a partial protection against $\mathrm{H}_{2} \mathrm{O}_{2}$-induced toxicity, which was suggested to be associated with adaptation to oxidative stress (Cunha-Oliveira et al., 2006c).

MDMA-induced oxidative stress was also reported. Metabolization of MDMA to catechol or quinone compounds, which are capable of forming free radicals, may be responsible for the oxidative damage induced by MDMA (Green et al., 2003, for review). Thioether MDMA metabolites may also induce oxidative stress in neurons (Capela et al., 2007b). In addition, since MDMA also induces dopamine release in rats (Amato et al., 2007), dopamine metabolism may also explain MDMAinduced oxidative stress.

Hydroxyl radical formation was reported in the hippocampus and striatum of rats upon peripheral injection of MDMA (Shankaran et al., 2001), and was dependent on SERT activity (Shankaran et al., 1999). Furthermore, depletion of GSH upon MDMA exposure was observed in vitro in rat cortical neurons (Capela et al., 2007a) and in vivo in the mouse hippocampus, along with a decrease in $\mathrm{Cu} / \mathrm{Zn}$ SOD activity (Frenzilli et al., 2007). In vivo exposure to MDMA was also reported to induce an increase in lipoperoxides and protein carbonyls, accompanied by mitochondrial DNA deletions, in isolated mitochondria from adolescent rat brains (Alves et al., 2007). In addition, lipoperoxides were detected by other authors in the brains of rats exposed to MDMA (Sprague and Nichols, 1995; Colado et al., 1997). Another evidence of MDMA induced-oxidative stress is the fact that transgenic mice that overexpress $\mathrm{Cu} / \mathrm{Zn}$ SOD are resistant to MDMA toxicity (Jayanthi et al., 1999).

2.4.1.3. Cocaine and oxidative stress. The occurrence of oxidative stress in neurons, upon exposure to cocaine has been much less studied, when compared to amphetamine and amphetamine derivatives. Cocaine exposure has been reported to increase $\mathrm{H}_{2} \mathrm{O}_{2}$ in the prefrontal cortex and in the striatum of rats (Dietrich et al., 2005). Cocaine exposure was also shown to induce a decrease in catalase activity (Macedo et al., 2005), as well as an increase in SOD and GPx activities (Dietrich et al., 2005) in the cortex and in the striatum of animals. The levels of antioxidants such as GSH or reduced vitamin $\mathrm{E}$ have been also shown to be decreased upon cocaine exposure (Poon et al., 2007; Lipton et al., 2003). Furthermore, cocaine exposure also results in oxidative injury in the brain, as indicated by an increase in lipid peroxidation (Bashkatova et al., 2006) and oxidation of proteins (Poon et al., 2007). Adaptation to oxidative stress induced by cocaine may explain the significant protection against $\mathrm{H}_{2} \mathrm{O}_{2}$ toxicity observed in PC12 cells, upon chronic exposure to cocaine (Cunha-Oliveira et al., 2006c). 
Table 2 - Summary of recent studies showing evidences of oxidative stress induced by amphetamine or amphetamine derivatives

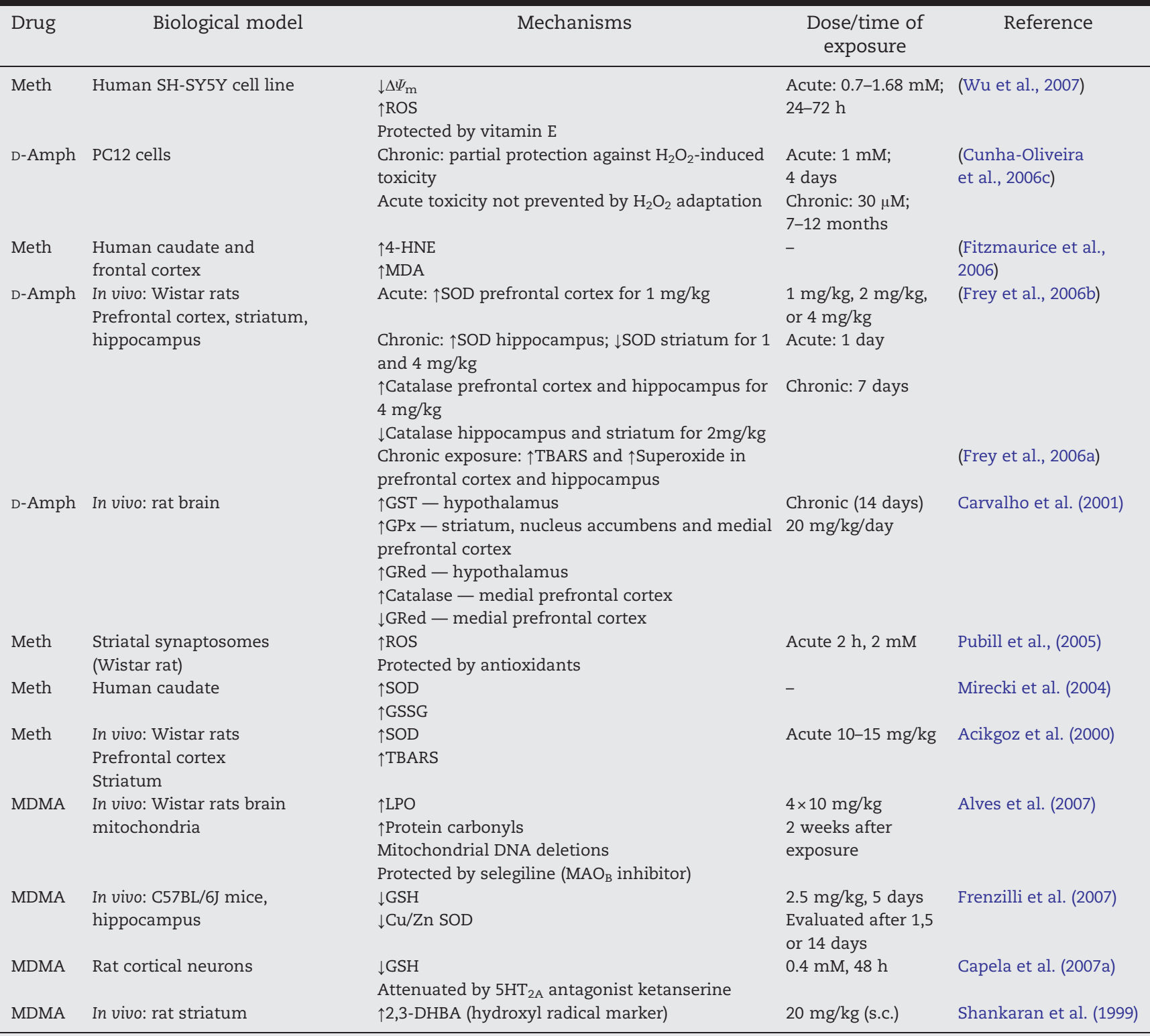

Abbreviations: $\Delta \Psi_{\mathrm{m}}$ - mitochondrial potential, D-Amph — D-amphetamine, 2,3 DHBA - 2,3-dihydroxybenzoic acid, GSH — reduced glutathione, GST - glutathione-S-transferase, GPx - glutathione peroxidase, GRed - glutathione reductase, HNE - hydroxynonenal, meth - methamphetamine, LPO - lipoperoxides, MDA - malondialdehyde, NAC - N-acetyl cysteine, NOS — nitric oxide synthase, ROS - reactive oxygen species, SOD — superoxide dismutase, TBARS - thiobarbituric acid reactive substances.

The results of recent studies presenting evidences of oxidative stress induced by cocaine are summarized in Table 3.

2.4.1.4. Opiates and oxidative stress. Although there is much less literature presenting evidences about opiateinduced oxidative stress in the nervous system when compared to the psychostimulants, there is recent evidence that the effects of morphine and heroin exposures in the brain and spinal tissues may involve oxidative stress. Heroin was shown to induce a decrease in the activities of SOD, catalase and GPx in the mouse brain (Qiusheng et al., 2005; Xu et al., 2006). Moreover, morphine induced a decrease in GSH levels in the rat (Guzman et al., 2006) and rabbit brains
(Ozmen et al., 2007), and also a decrease in unsaturated fatty acids in the rabbit nervous system (Ozmen et al., 2007). Oxidative lesions were also observed in the brains of opiateexposed animals. Morphine exposure induced an increase in lipid peroxidation (Ozmen et al., 2007) and heroin exposure induced an increase in oxidative DNA damage, protein oxidation and lipid peroxidation (Qiusheng et al., 2005; Xu et al., 2006). Partial protection against $\mathrm{H}_{2} \mathrm{O}_{2}$ toxicity was observed in PC12 cells chronically exposed to street heroin, indicating some degree of adaptation to oxidative stress (Cunha-Oliveira et al., 2006b).

The results of recent studies presenting evidences of oxidative stress induced by opiates are summarized in Table 4. 
Table 3 - Summary of recent studies showing evidences of oxidative stress induced by cocaine

\begin{tabular}{|c|c|c|c|}
\hline Biological model & Mechanisms & Dose/time of exposure & Reference \\
\hline PC12 cells & $\begin{array}{l}\text { Chronic: partial protection against } \\
\mathrm{H}_{2} \mathrm{O}_{2} \text {-induced toxicity } \\
\text { Acute toxicity not prevented by } \mathrm{H}_{2} \mathrm{O}_{2} \\
\text { adaptation }\end{array}$ & $\begin{array}{l}\text { Acute: } 3 \mathrm{Mm} ; 4 \text { days } \\
\text { Chronic: } 30 \mu \mathrm{M} \text {; 7-12 months }\end{array}$ & $\begin{array}{l}\text { Cunha-Oliveira et al. } \\
(2006 \mathrm{c})\end{array}$ \\
\hline $\begin{array}{l}\text { In vivo: prenatal exposure - rat } \\
\text { hippocampus and cortex }\end{array}$ & $\begin{array}{l}\text { Nitric Oxide } \\
\text { TBARS }\end{array}$ & $\begin{array}{l}\text { Repeated: } 20 \mathrm{mg} / \mathrm{kg} / \text { day } \\
4 \text { days }\end{array}$ & Bashkatova et al. (2006) \\
\hline Human neuronal progenitor cells & $\begin{array}{l}\text { Protein carbonyl } \\
\text { Protein HNE } \\
\downarrow \text { GSH }\end{array}$ & $\begin{array}{l}\text { Acute: } 1 \mu \mathrm{M} ; 30 \mathrm{~min} \text {; analysed } \\
\text { after } 6-96 \mathrm{~h}\end{array}$ & Poon et al. (2007) \\
\hline $\begin{array}{l}\text { In vivo: Swiss mice, striatum and } \\
\text { frontal cortex }\end{array}$ & $\begin{array}{l}\text { Low dose: } \downarrow \text { catalase in striatum } \\
\text { High dose: } \downarrow \text { catalase activity in cortex } \\
\text { and striatum }\end{array}$ & $\begin{array}{l}\text { Low dose: } 10-30 \mathrm{mg} / \mathrm{kg} \\
\text { High dose: } 90 \mathrm{mg} / \mathrm{kg}\end{array}$ & Macedo et al. (2005) \\
\hline $\begin{array}{l}\text { In vivo: rat - frontal cortex and } \\
\text { striatum }\end{array}$ & $\begin{array}{l}\uparrow \mathrm{H}_{2} \mathrm{O}_{2} \\
\text { Lipoperoxidation } \\
\downarrow \text { Complex I activity } \\
\uparrow \mathrm{SOD}, \uparrow \mathrm{GPx}\end{array}$ & $\begin{array}{l}20 \mathrm{mg} / \mathrm{kg} / \text { day } \\
\text { Acute }-1 \text { day } \\
\text { Chronic }-10 \text { days }\end{array}$ & Dietrich et al. (2005) \\
\hline $\begin{array}{l}\text { In vivo: prenatal exposure - rat } \\
\text { brain }\end{array}$ & $\begin{array}{l}\downarrow \text { GSH } \\
\downarrow \text { reduced Vit E } \\
\uparrow \text { oxidized Vit E }\end{array}$ & Single & Lipton et al. (2003) \\
\hline
\end{tabular}

\subsubsection{Cell death by apoptosis caused by drugs of abuse} Induction of neuronal cell death by apoptosis by some drugs of abuse has been documented. Programmed cell death can occur through several tightly regulated pathways. Thus, identification of cell death pathways induced by the drugs of abuse may lead to strategies to prevent cell damage induced by these drugs.

One of the most characterized types of cell death is apoptosis. Morphological hallmarks of apoptotic cells are cell shrinkage, fragmentation into membrane-bound apoptotic bodies, chromatin condensation and fragmentation. Two main molecular pathways of apoptosis have been character- ized, one being activated by extrinsic signals, involving the activation of death-receptors in the cell membrane, and another activated by intrinsic stimuli and involving mitochondrial membrane permeabilization. These pathways may involve the activation of cysteine aspartic proteases, named caspases, which are activated by proteolysis, or may be caspase independent (Kroemer and Martin, 2005).

2.4.2.1. Amphetamines and apoptosis. Exposure to amphetamine or amphetamine derivatives has been shown to induce apoptotic features in animals and in cell models (Table 5). Previous reviews have addressed this subject (Cadet et al.,

\section{Table 4 - Summary of recent studies showing evidences of oxidative stress induced by opiates}

\begin{tabular}{|c|c|c|c|c|}
\hline Drug & Biological model & Mechanisms & Dose/time of exposure & Reference \\
\hline Morphine & $\begin{array}{l}\text { In vivo: rabbit; brain and } \\
\text { spinal tissues }\end{array}$ & $\begin{array}{l}\uparrow \text { Lipid peroxidation } \\
\downarrow \text { GSH } \\
\downarrow \text { Unsaturated fatty acids }\end{array}$ & $6 \mathrm{mg} / \mathrm{kg}$ intraspinal & Ozmen et al. (2007) \\
\hline Heroin & PC12 cells & $\begin{array}{l}\text { Chronic: protection against } \mathrm{H}_{2} \mathrm{O}_{2}- \\
\text { induced toxicity } \\
\text { Acute toxicity potentiated upon } \\
\mathrm{H}_{2} \mathrm{O}_{2} \text { adaptation }\end{array}$ & $\begin{array}{l}\text { Acute: } 128 \mu \mathrm{g} / \mathrm{ml}(215 \mu \mathrm{M}) ; 4 \text { days } \\
\text { Chronic: } 10 \mu \mathrm{M} \text {; 7-12 months }\end{array}$ & Cunha-Oliveira et al. (2006b) \\
\hline Heroin & In vivo: mouse brain & $\begin{array}{l}\downarrow \mathrm{SOD} \\
\downarrow \mathrm{CAT} \\
\downarrow \mathrm{GPx} \\
\uparrow \text { Oxidative damage to DNA, lipids } \\
\text { and proteins }\end{array}$ & i.p. & Xu et al. (2006) \\
\hline Morphine & In vivo: rat brain & $\downarrow \mathrm{GSH}$ & Single i.p. 3,6 or $12 \mathrm{mg} / \mathrm{kg}$ & Guzman et al. (2006) \\
\hline Heroin & In vivo: mouse brain & $\begin{array}{l}\downarrow \text { GSH/GSSG } \\
\downarrow \text { SOD } \\
\downarrow \text { Catalase } \\
\downarrow \text { GPx } \\
\uparrow 8 \text {-OhdG } \\
\uparrow \text { Protein carbonyls } \\
\uparrow \text { MDA }\end{array}$ & i.p. & Qiusheng et al. (2005) \\
\hline
\end{tabular}

Abbreviations: GSH — reduced glutathione; SOD — superoxide dismutase; CAT — catalase; GPx — glutathione peroxidase; GSSG — oxidized glutathione; 8-OHdG - 8-hydroxy-2-deoxyguanosine; MDA — malondialdehyde, i.p. — intraperitoneal. 
Table 5 - Summary of recent studies that analyse neuronal apoptosis induced by amphetamines

\begin{tabular}{|c|c|c|c|c|}
\hline Drug & Biological model & Mechanisms & Dose/time of exposure & Reference \\
\hline Meth, MDMA & In vivo: rat brain, cortex & $\begin{array}{l}\text { Active caspase-3 } \\
\text { Active calpain-1 }\end{array}$ & $\begin{array}{l}40 \mathrm{mg} / \mathrm{kg} \\
\text { Meth: } 48 \mathrm{~h} \\
\text { MDMA: } 24 \mathrm{~h}\end{array}$ & Warren et al. (2007) \\
\hline MDMA & PC12 cells & Chromatin condensation & $3 \mathrm{mM}, 24 \mathrm{~h}$ & Milhazes et al. (2006) \\
\hline MDMA & Rat cortical neurons & Stimulation of $5 \mathrm{HT}_{2 \mathrm{~A}}$ receptor & $200-1600 \mu \mathrm{M}$ & Capela et al. (2006b) \\
\hline Meth & In vivo: mouse striatum & TUNEL-positive cells & $\begin{array}{l}30 \mathrm{mg} / \mathrm{kg}, \text { i.p. } \\
\text { Tested } 24 \text { h later }\end{array}$ & Zhu et al. (2006) \\
\hline D-Amph & Rat cortical neurons & $\begin{array}{l}\text { Caspases }-2,-9 \text { and }-3 \\
\downarrow \Delta \Psi_{\mathrm{m}} \\
\text { Apoptotic nuclear morphology }\end{array}$ & Acute $(24$ h) $500 \mu \mathrm{M}$ & $\begin{array}{l}\text { Cunha-Oliveira et al. } \\
\text { (2006a) }\end{array}$ \\
\hline Meth & In vivo: rat striatum & $\begin{array}{l}\text { Multiple injection }-\uparrow B a x \\
\text { No caspase- } 3 \text { activation }\end{array}$ & $\begin{array}{l}\text { Multiple injection }(4 \times 5 \mathrm{mg} / \mathrm{kg} \text {, i.p.) } \\
\text { Single injection }(1 \times 20 \mathrm{mg} / \mathrm{kg} \text {, i.p.) }\end{array}$ & Pereira et al. (2006b) \\
\hline D-Amph & $\begin{array}{l}\text { In vivo: mouse medium } \\
\text { spiny striatal neurons }\end{array}$ & $\begin{array}{l}\text { Mitochondrial apoptotic pathway } \\
\text { Caspase- } 3, \uparrow p 53, \uparrow \text { Bax, } \downarrow \text { Bcl-2 } \\
\text { Bax-KO mice are resistant }\end{array}$ & $\begin{array}{l}\text { Repeated: } 10 \mathrm{mg} / \mathrm{kg} \text {, } 4 \text { times, every } \\
2 \mathrm{~h}\end{array}$ & Krasnova et al. (2005) \\
\hline Meth, MDMA & $\begin{array}{l}\text { Rat cerebellar granule } \\
\text { cells }\end{array}$ & Caspase-3; ROS, cytochrome c & Acute $(48 \mathrm{~h}, 1-5 \mathrm{mM})$ & Jimenez et al. (2004) \\
\hline D-Amph & PC12 cells & $\begin{array}{l}\text { Caspase-3 } \\
\text { Cytochrome c }\end{array}$ & Acute $(5 \mathrm{~h}, 300 \mu \mathrm{M})$ & Oliveira et al. (2003) \\
\hline D-Amph & PC12 cells & $\begin{array}{l}\downarrow \text { ATP/ADP } \\
\text { Apoptotic nuclear morphology }\end{array}$ & Acute (96 h, 1 mM) & Oliveira et al. (2002) \\
\hline Meth & In vivo: mouse striatum & $\uparrow \mathrm{p} 53 ; \downarrow \mathrm{Bcl}-2$ & $\begin{array}{l}\text { Repeated: } 10 \mathrm{mg} / \mathrm{kg} \text {, } 4 \text { times, every } \\
2 \mathrm{~h}\end{array}$ & Imam et al. (2001) \\
\hline $\begin{array}{l}\text { D-Amph, Meth, } \\
\text { MDMA }\end{array}$ & Neocortical neurons & Bcl-xL/s changes, c-Jun & $\begin{array}{l}\text { Acute }(1-96 \mathrm{~h}, 125 \mu \mathrm{M}-1 \mathrm{mM}) \\
\text { Apoptosis evaluated at } 96 \mathrm{~h}, 500 \mu \mathrm{M}\end{array}$ & Stumm et al. (1999) \\
\hline Meth & $\begin{array}{l}\text { Immortalized neural cells } \\
\text { from rat mesencephalon }\end{array}$ & $\begin{array}{l}\text { Apoptosis } \\
\text { Protection by Bcl-2 overexpression } \\
\text { ROS? }\end{array}$ & $1-3 \mathrm{mM}(24 \mathrm{~h})$ & Cadet et al. (1997) \\
\hline
\end{tabular}

Abbreviations: Meth — methamphetamine, D-Amph — D-amphetamine, MDMA — ecstasy, MDA — malondialdehyde.

2007). The activation of caspases upon amphetamine exposure has been reported in the rat frontal cortex (Warren et al., 2007) and medium spiny striatal neurons (Krasnova et al., 2005) of exposed animals, as well as in rat cortical neurons (Cunha-Oliveira et al., 2006a), rat cerebellar granule cells (Jimenez et al., 2004) and PC12 cells (Oliveira et al., 2003). Caspase activation mediated by $\mathrm{D}$-amphetamine or methamphetamine has been suggested to be mediated by the mitochondrial apoptotic pathway, as indicated by the observation of cytochrome c release (Oliveira et al., 2003; Jimenez et al., 2004), accompanied by a decrease in mitochondrial potential (Cunha-Oliveira et al., 2006a), and a decrease in Bcl2/Bax levels (Krasnova et al., 2005; Imam et al., 2001). Moreover, Bcl-2 overexpression was shown to protect mesencephalic immortalized cells from methamphetamine-induced apoptosis (Cadet et al., 1997). Some studies also implicated p53 in the apoptotic process induced by D-amphetamine (Krasnova et al., 2005) and methamphetamine (Imam et al., 2001). Morphological features of apoptosis induced by D-amphetamine were observed upon in vitro (Oliveira et al., 2002; CunhaOliveira et al., 2006a) and in vivo (Dietrich et al., 2005) exposure. Furthermore, TUNEL-positive cells were observed in the striatum of methamphetamine exposed mice (Zhu et al., 2006).

MDMA also induces apoptotic features in PC12 cells (Milhazes et al., 2006) and in rat cortical neurons (Capela et al., 2006b). MDMA-induced apoptosis in rat cortical neurons seems to be dependent on $5-\mathrm{HT}_{2 \mathrm{~A}}$ receptor activation (Capela et al., 2006b).
2.4.2.2. Cocaine and apoptosis. Cocaine neurotoxicity has been associated with the induction of biochemical features of apoptosis, such as activation of caspases (Dey et al., 2007; CunhaOliveira et al., 2006a; Imam et al., 2005; Oliveira et al., 2003; Mitchell and Snyder-Keller, 2003), loss of mitochondrial potential and cytochrome c release (Oliveira et al., 2003; Cunha-Oliveira et al., 2006a). However, morphological features of apoptosis were not evident upon in vivo (Dietrich et al., 2005) or in vitro (Oliveira et al., 2002; Cunha-Oliveira et al., 2006a) exposure to cocaine, except in one study from Nassogne et al. (1997). Cell death induced by cocaine in human neuronal progenitor cells, involving cytochrome $c$ release, seems to be preceded by oxidative stress (Poon et al., 2007). Recent studies showing evidences of apoptosis induced by cocaine are summarized in Table 6.

2.4.2.3. Opiates and apoptosis. Although there are some studies reporting heroin (Fecho and Lysle, 2000) and morphine (Bhat et al., 2004) cytotoxicity, the molecular mechanisms of neurotoxicity induced by these opiate drugs is scarcely documented. However, a few studies have shown the involvement of apoptosis in neuronal dysfunction induced by opiates in mouse cortex and hippocampus (Tramullas et al., 2008), rat spinal cord (Mao et al., 2002; Lim et al., 2005), in fetal human neurons (Hu et al., 2002), rat cortical neurons (Cunha-Oliveira et al., 2007) and in PC12 cells (Oliveira et al., 2002; Oliveira et al., 2003) (Table 7). Street heroin and morphine seem to induce apoptosis involving cytochrome c release (Oliveira et al., 2003; Cunha-Oliveira et al., 2007), caspase activation (Lim et al., 2005; Oliveira et al., 2003; Mao et al., 2002; Hu et al., 2002; 
Table 6 - Summary of recent studies presenting evidences of neuronal apoptosis induced by cocaine

\begin{tabular}{|c|c|c|c|}
\hline Biological model & Mechanisms & Dose/time of exposure & Reference \\
\hline Fetal locus coeruleus neurons & $\begin{array}{l}\text { Bax/Bcl-2 } \\
\text { Caspase-3 }\end{array}$ & Acute $(30 \mathrm{~min}-24 \mathrm{~h}) 500 \mathrm{ng} / \mathrm{ml}$ & Dey et al. (2007) \\
\hline Human neuronal progenitor cells & $\begin{array}{l}\text { Oxidative stress ( } 48 \mathrm{~h} \text { ) } \\
\text { Cell death (LDH leakage, } 72 \mathrm{~h} \text { ) }\end{array}$ & Acute (30 min) & Poon et al. (2007) \\
\hline Rat cortical neurons & $\begin{array}{l}\text { Loss of metabolic viability } \\
\text { Caspases }-2,-9 \text { and }-3 \\
\downarrow \Delta \Psi_{\mathrm{m}} \\
\text { Mitochondrial apoptotic pathway } \\
\text { No apoptotic morphology }\end{array}$ & Acute $(24 \mathrm{~h}) 1 \mathrm{mM}$ & Cunha-Oliveira et al. (2006a) \\
\hline PC12 cells & $\begin{array}{l}\text { Immediate early genes } \\
\text { Transcription factors } \\
\text { Caspases }\end{array}$ & Acute $(24$ h) $50-2500 \mu \mathrm{M}$ & Imam et al. (2005) \\
\hline $\begin{array}{l}\text { In vivo: rat - dopaminergic } \\
\text { brain structures }\end{array}$ & No apoptosis & $\begin{array}{l}20 \mathrm{mg} / \mathrm{kg} / \text { day } \\
\text { Acute }-1 \text { day } \\
\text { Chronic }-10 \text { days }\end{array}$ & Dietrich et al. (2005) \\
\hline PC12 cells & $\begin{array}{l}\text { Caspase-3 } \\
\text { Cytochrome c }\end{array}$ & Acute $(5 \mathrm{~h}) 300 \mu \mathrm{M}$ & Oliveira et al. (2003) \\
\hline $\begin{array}{l}\text { In vivo: prenatal exposure - } \\
\text { rat brains }\end{array}$ & C-Fos & $\begin{array}{l}\text { Acute (binge } 3 \times 15 \mathrm{mg} / \mathrm{kg}-1 \mathrm{~h} \\
\text { interval in the day before birth } \\
\text { Evaluated } 24 \mathrm{~h} \text { after birth }\end{array}$ & Mitchell and Snyder-Keller (2003) \\
\hline Mouse cortical cocultures & $\begin{array}{l}\text { DNA fragmentation } \\
\text { Cromatin condensation } \\
\downarrow \text { MAP- } 2 \text { content }\end{array}$ & $0.5 \mathrm{mM}, 48-108 \mathrm{~h}$ & Nassogne et al. (1997) \\
\hline
\end{tabular}

Cunha-Oliveira et al., 2007) and a decrease in Bcl-2/Bax ratio (Mao et al., 2002; Cunha-Oliveira et al., 2007). Recently, it was shown that chronic heroin exposure induced the upregulation of the pro-apoptotic proteins Fas, FasL and Bad, in the mouse cortex and hippocampus (Tramullas et al., 2008). Morphological hallmarks of apoptosis have also been observed in in vitro models upon street heroin exposure (Oliveira et al., 2002; Cunha-Oliveira et al., 2007), and were prevented by using a broad-range caspase inhibitor. Moreover, TUNEL-positive cells were detected scattered in the brains of mice chronically exposed to heroin (Tramullas et al., 2008). In addition, we have recently shown that street heroin-induced apoptosis in rat cortical neurons also involves a significant loss of mitochondrial membrane potential (Cunha-Oliveira et al., 2007).

Although the extrinsic apoptotic pathway may be involved in heroin neurotoxicity, mitochondria seem to be important mediators of opiate-induced neurotoxic effects.

Table 7 - Summary of recent studies presenting evidences of neuronal apoptosis induced by opiates

\begin{tabular}{|c|c|c|c|c|}
\hline Drug & Biological model & Mechanisms & Dose/time of exposure & Reference \\
\hline Heroin & $\begin{array}{l}\text { In vivo: } \mathrm{C} 57 \mathrm{BL} / 6 \text { mice } \\
\text { Cortex and } \\
\text { hippocampus }\end{array}$ & $\begin{array}{l}\text { Cognitive ability and flexibility strongly impaired } \\
\uparrow \text { Fas, FasL, Bad } \\
\text { TUNEL-positive cells }\end{array}$ & $\begin{array}{l}5 \mathrm{mg} / \mathrm{kg} \text { (s.c.), } 12 \mathrm{~h} \text { intervals, } \\
2 \text { months }\end{array}$ & Tramullas et al. (2008) \\
\hline Heroin & Rat cortical neurons & $\begin{array}{l}\text { Cytochrome c release } \\
\downarrow \Delta \Psi_{\mathrm{m}} \\
\text { Caspase-2, -9 and -3 activation } \\
\downarrow \text { Bcl-2/Bax } \\
\text { Apoptotic nuclear morphology prevented by } \\
\text { caspase inhibitor }\end{array}$ & $128 \mu \mathrm{g} / \mathrm{ml}$ (215 $\mu \mathrm{M}$ heroin) $24 \mathrm{~h}$ & $\begin{array}{l}\text { Cunha-Oliveira et al. } \\
\text { (2007) }\end{array}$ \\
\hline Morphine & $\begin{array}{l}\text { In vivo: rat spinal } \\
\text { cord }\end{array}$ & Caspase-3, MAPK, PKA & $10 \mu \mathrm{g}$, twice daily, 7 days & Lim et al. (2005) \\
\hline Heroin & PC12 cells & $\begin{array}{l}\text { Cytochrome c } \\
\text { Caspase-3 }\end{array}$ & $30 \mu \mathrm{M}$ (without serum) $-5 \mathrm{~h}$ & Oliveira et al. (2003) \\
\hline Heroin & PC12 cells & $\begin{array}{l}\uparrow \text { Dopamine metabolism } \\
\text { Apoptotic nuclear morphology }\end{array}$ & $300 \mu \mathrm{M}-4$ days & Oliveira et al. (2002) \\
\hline Morphine & $\begin{array}{l}\text { In vivo: rat spinal } \\
\text { cord }\end{array}$ & $\begin{array}{l}\uparrow \text { Caspase-3 } \\
\uparrow \text { Bax } \\
\downarrow \text { Bcl-2, NMDA receptors }\end{array}$ & $20 \mu$ g, twice daily for 7 days & Mao et al. (2002) \\
\hline Morphine & $\begin{array}{l}\text { Fetal human } \\
\text { neurons }\end{array}$ & Caspase-3 & $1 \mu \mathrm{M}$ (without serum) -5 days & Hu et al. (2002) \\
\hline
\end{tabular}

Abbreviations: FasL — Fas ligand, MAPK — mitogen activated protein kinase, PKA — protein kinase A, NMDA — N-methyl-D-aspartate. 
2.4.2.4. Comparison between amphetamine, cocaine and street heroin effects - the role of mitochondrial dysfunction. Amphetamine and amphetamine derivatives induce apoptosis upon acute and repeated exposures (see Table 5). Apoptotic pathways induced by amphetamine and methamphetamine in neurons seem to be mainly mediated by the mitochondrial apoptotic pathway, associated with a decrease in Bcl-2 levels and direct interference with the mitochondrial transmembrane potential. Moreover, cocaine has been described to activate the mitochondrial apoptotic pathway (see Table 6). Cocaine seems to be less toxic than amphetamine, and in most studies apoptotic neurons were not observed upon exposure to cocaine (Dietrich et al., 2005; Cunha-Oliveira et al., 2006a; Oliveira et al., 2002). The differential effects of cocaine and amphetamine may be explained by the fact that these drugs have distinct effects in the mitochondria, as assessed by using NT-2 rho zero (depleted of mitochondrial DNA) versus NT-2 rho plus cells (CunhaOliveira et al., 2006a). Cocaine toxicity was less evident in NT-2 rho zero cells, compared to NT-2 rho plus cells, indicating that the mitochondrial respiratory chain is partially involved in cocaine toxicity in NT-2 rho plus cells. In contrast, amphetamine toxicity was potentiated in NT-2 rho zero cells. Considering that NT-2 rho zero cells do not have a functional mitochondrial respiratory chain and that amphetamine induced a significant loss of mitochondrial potential in cortical neurons (Cunha-Oliveira et al., 2006a), the effect of amphetamine in NT-2 rho zero cells can be explained by the inability of rho zero cells to cope with stimuli that largely affected the mitochondrial potential. Also, in contrast with cocaine, amphetamine caused a decrease in intracellular ATP/ADP (Oliveira et al., 2002). Street heroin exposure also appears to affect the mitochondria in neurons, by inducing a significant loss of mitochondrial potential, which was associated with the activation of the mitochondrial apoptotic pathway. However, the effects of street heroin might not be solely attributed to heroin itself, since heroin hydrochloride did not exhibit the same apoptotic effects (Cunha-Oliveira et al., 2007), but implicate that the cocktail of compounds consumed by heroin addicts may increase the neurotoxic risk to which they are exposed.

Many studies reported in this review show biochemical and morphological evidences of cell death induced by drugs of abuse using in vitro models. Indeed, in vivo studies may underestimate cell death occurring upon exposure to the drugs of abuse, because phagocytes remove apoptotic cells (Li et al., 2003). Moreover, in vivo, different cells in a tissue are not exposed to the toxic agents at the same time, as it occurs in vitro. In vivo, cell death certainly initiates and progresses at different time points, and thus may be difficult to detect. In addition, in vivo, brain cells are organized in circuits and the presence of more than one cell type and the interactions that occur between cells may alter cell susceptibility. These reasons may affect the analysis of dying cells in a tissue. Therefore, the study of cell death induced by the drugs of abuse using in vitro systems may help to determine the susceptibility of different cell types in the nervous system and may thus be useful to identify molecular targets for neuroprotective strategies.

\section{Inhibition of neurogenesis}

Besides being toxic to neurons, drugs of abuse have been also shown to induce a decrease in hippocampal neurogenesis (reviewed by Eisch and Harburg, 2006), compromising the capacity of the brain to generate new neurons.

In the adult mammalian brain there are two main neurogenic regions, the subventricular zone (SVZ) and the subgranular zone (SGZ) of the dentate gyrus in the hippocampus (reviewed by Gage, 2002).

Morphine and heroin induce a decrease in SGZ neurogenesis (Eisch et al., 2000). Cocaine (Yamaguchi et al., 2004; Mackowiak

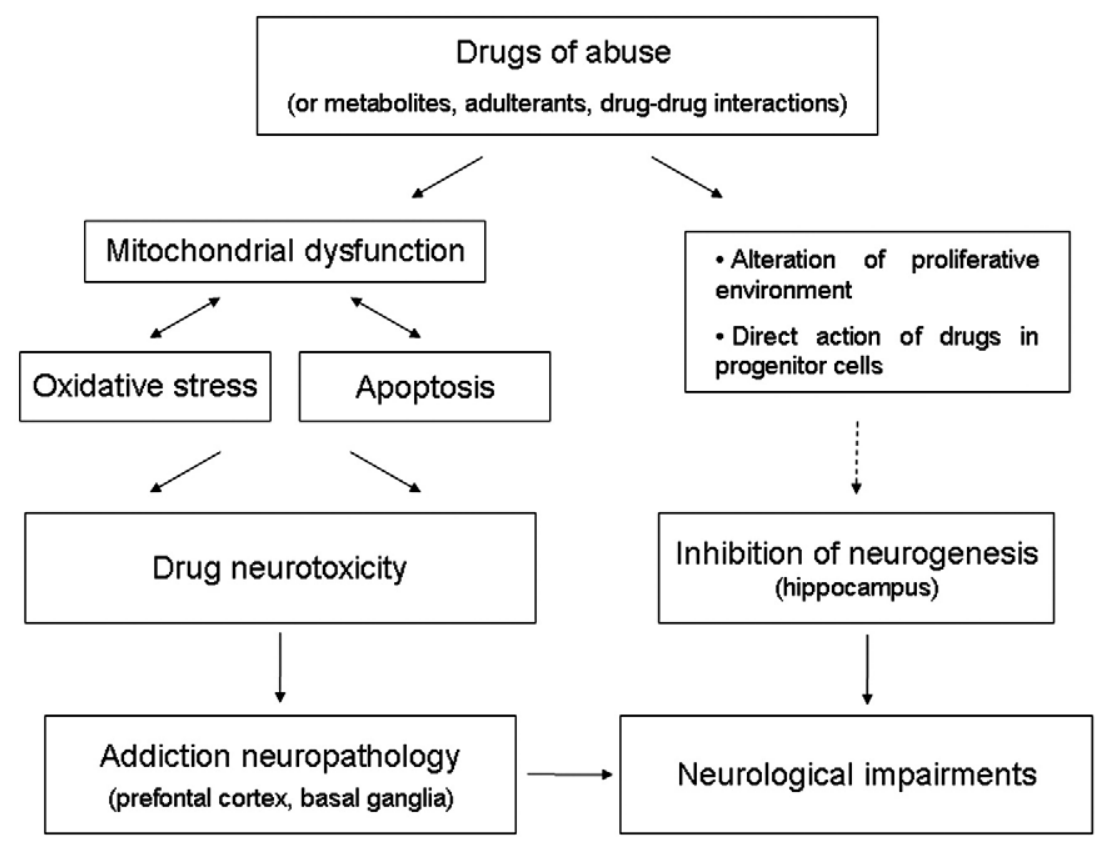

Fig. 2 - Molecular and cellular mechanisms involved in the neurotoxicity of drugs of abuse, which may explain the neuropathology of addiction. 
et al., 2005) and methamphetamine (Teuchert-Noodt et al., 2000) were also reported to decrease hippocampal neurogenesis. Repeated or chronic exposure seems to be required to observe the inhibition in adult hippocampal neurogenesis induced by opiates or psychostimulants (Eisch and Harburg, 2006).

Although the mechanisms involved in the decrease in neurogenesis induced by drugs of abuse are just starting to be investigated, they may be related with alteration of the proliferative environment, direct action of the drugs of abuse in the progenitor cells and/or alteration of the cell cycle of SGZ (Eisch and Harburg, 2006).

The effect of drugs of abuse on neurogenesis seems to be selective for the SGZ, and does not seem to occur in the SVZ (Nixon and Crews, 2004). A decrease in hippocampal neurogenesis may result in long-lasting effects on learning, memory and cognition.

\section{Conclusions}

Addictions are the most expensive neuropsychiatric disorders, with both medical and social consequences. In the last decades, much progress has been achieved in the clarification of the molecular and cellular mechanisms of action of the drugs of abuse in the brain, and drug addiction is now considered a brain disease, as the abuse of drugs was shown to have both acute and chronic neurotoxic consequences. The mechanisms involved in the neurotoxicity of these drugs include oxidative stress, apoptosis, mitochondrial dysfunction and inhibition of neurogenesis (Fig. 2).

Despite this progress, efficient treatments that prevent relapse have not been developed (Kreek et al., 2002; Volkow and Li, 2005). Relapse is probably mediated by the long-lasting changes in brain function induced by the drugs of abuse. Thus, interference with the long-term molecular and cellular effects of the drugs of abuse may constitute important pharmacological targets to prevent relapse.

Thus, understanding the mechanisms that underlie the brain dysfunction observed in drug-addicted individuals may contribute to improve the treatment of drug addiction. Molecular and cellular studies suggest that other therapeutic targets may be explored in the future, such as the prevention drug-induced neuronal dysfunction and neurotoxicity.

\section{Acknowledgments}

The authors acknowledge the financial support from Fundação para a Ciência e a Tecnologia, Portugal, references SFRH/ BD/10910/2002 and POCI/SAU-FCF/58330/2004.

\section{RE F E R E N C E S}

Abekawa, T., Ohmori, T., Koyama, T., 1994. Effects of repeated administration of a high dose of methamphetamine on dopamine and glutamate release in rat striatum and nucleus accumbens. Brain Res. 643, 276-281.
Acikgoz, O., Gonenc, S., Kayatekin, B.M., Pekcetin, C., Uysal, N., Dayi, A., Semin, I., Gure, A., 2000. The effects of single dose of methamphetamine on lipid peroxidation levels in the rat striatum and prefrontal cortex. Eur. Neuropsychopharmacol. 10, 415-418.

Alves, E., Summavielle, T., Alves, C.J., Gomes-Da-Silva, J., Barata, J.C., Fernandes, E., Bastos, M.L., Tavares, M.A., Carvalho, F., 2007. Monoamine oxidase-B mediates ecstasy-induced neurotoxic effects to adolescent rat brain mitochondria. J. Neurosci. 27, 10203-10210.

Amara, S.G., Kuhar, M.J., 1993. Neurotransmitter transporters: recent progress. Annu. Rev. Neurosci. 16, 73-93.

Amato, J.L., Bankson, M.G., Yamamoto, B.K., 2007. Prior exposure to chronic stress and MDMA potentiates mesoaccumbens dopamine release mediated by the $5-\mathrm{HT}(1 \mathrm{~B})$ receptor. Neuropsychopharmacology 32, 946-954.

Anderzhanova, E., Rayevsky, K.S., Saransaari, P., Riitamaa, E., Oja, S.S., 2002. Effects of acute toxic doses of psychostimulants on extracellular levels of excitatory amino acids and taurine in rats: comparison of D-amphetamine and sydnocarb. Ann. N. Y. Acad. Sci. 965, 193-203.

Bajo, M., Crawford, E.F., Roberto, M., Madamba, S.G., Siggins, G.R., 2006. Chronic morphine treatment alters expression of $\mathrm{N}$-methyl-D-aspartate receptor subunits in the extended amygdala. J. Neurosci. Res. 83, 532-537.

Bartzokis, G., Beckson, M., Ling, W., 1996. Clinical and MRI evaluation of psychostimulant neurotoxicity. NIDA Res. Monogr. 163, 300-317.

Bashkatova, V., Meunier, J., Vanin, A., Maurice, T., 2006. Nitric oxide and oxidative stress in the brain of rats exposed in utero to cocaine. Ann. N. Y. Acad. Sci. 1074, 632-642.

Benedi, J., Arroyo, R., Romero, C., Martin-Aragon, S., Villar, A.M., 2004. Antioxidant properties and protective effects of a standardized extract of Hypericum perforatum on hydrogen peroxide-induced oxidative damage in PC12 cells. Life Sci. 75, 1263-1276.

Bhat, R.S., Bhaskaran, M., Mongia, A., Hitosugi, N., Singhal, P.C., 2004. Morphine-induced macrophage apoptosis: oxidative stress and strategies for modulation. J. Leukoc. Biol. 75, 1131-1138.

Bisaga, A., Comer, S.D., Ward, A.S., Popik, P., Kleber, H.D., Fischman, M.W., 2001. The NMDA antagonist memantine attenuates the expression of opioid physical dependence in humans. Psychopharmacology (Berl) 157, 1-10.

Bowyer, J.F., Frame, L.T., Clausing, P., Nagamoto-Combs, K., Osterhout, C.A., Sterling, C.R., Tank, A.W., 1998. Long-term effects of amphetamine neurotoxicity on tyrosine hydroxylase mRNA and protein in aged rats. J. Pharmacol. Exp. Ther. 286, 1074-1085.

Brown, J.M., Hanson, G.R., Fleckenstein, A.E., 2001. Regulation of the vesicular monoamine transporter-2: a novel mechanism for cocaine and other psychostimulants. J. Pharmacol. Exp. Ther. 296, 762-767.

Bunney, E.B., Appel, S.B., Brodie, M.S., 2001. Electrophysiological effects of cocaethylene, cocaine, and ethanol on dopaminergic neurons of the ventral tegmental area. J. Pharmacol. Exp. Ther. 297, 696-703.

Buttner, A., Mall, G., Penning, R., Weis, S., 2000. The neuropathology of heroin abuse. Forensic Sci. Int. 113, 435-442.

Cadet, J.L., Brannock, C., 1998. Free radicals and the pathobiology of brain dopamine systems. Neurochem Int 32, 117-131.

Cadet, J.L., Ordonez, S.V., Ordonez, J.V., 1997. Methamphetamine induces apoptosis in immortalized neural cells: protection by the proto-oncogene, bcl-2. Synapse 25, 176-184.

Cadet, J.L., Krasnova, I.N., Jayanthi, S., Lyles, J., 2007. Neurotoxicity of substituted amphetamines: molecular and cellular mechanisms. Neurotox. Res. 11, 183-202.

Capela, J.P., Meisel, A., Abreu, A.R., Branco, P.S., Ferreira, L.M., Lobo, A.M., Remiao, F., Bastos, M.L., Carvalho, F., 2006a. Neurotoxicity 
of ecstasy metabolites in rat cortical neurons, and influence of hyperthermia. J. Pharmacol. Exp. Ther. 316, 53-61.

Capela, J.P., Ruscher, K., Lautenschlager, M., Freyer, D., Dirnagl, U., Gaio, A.R., Bastos, M.L., Meisel, A., Carvalho, F., 2006 b. Ecstasy-induced cell death in cortical neuronal cultures is serotonin 2A-receptor-dependent and potentiated under hyperthermia. Neuroscience 139, 1069-1081.

Capela, J.P., Fernandes, E., Remiao, F., Bastos, M.L., Meisel, A., Carvalho, F., 2007a. Ecstasy induces apoptosis via 5-HT(2A)-receptor stimulation in cortical neurons. Neurotoxicology 28, 868-875.

Capela, J.P., Macedo, C., Branco, P.S., Ferreira, L.M., Lobo, A.M., Fernandes, E., Remião, F., Bastos, M.L., Dirnagl, U., Meisel, A., Carvalho, F., 2007b. Neurotoxicity mechanisms of thioether ecstasy metabolites. Neuroscience 146, 1743-1757.

Carlezon Jr., W.A., Duman, R.S., Nestler, E.J., 2005. The many faces of CREB. Trends Neurosci. 28, 436-445.

Carvalho, F., Fernandes, E., Remiao, F., Gomes-Da-Silva, J., Tavares, M.A., Bastos, M.D., 2001. Adaptative response of antioxidant enzymes in different areas of rat brain after repeated D-amphetamine administration. Addict Biol. 6, 213-221.

Chieng, B., Williams, J.T., 1998. Increased opioid inhibition of GABA release in nucleus accumbens during morphine withdrawal. J. Neurosci. 18, 7033-7039.

Colado, M.I., O'Shea, E., Granados, R., Murray, T.K., Green, A.R., 1997. In vivo evidence for free radical involvement in the degeneration of rat brain 5-HT following administration of MDMA ('ecstasy') and p-chloroamphetamine but not the degeneration following fenfluramine. Br. J. Pharmacol. 121, 889-900.

Cole, R.L., Konradi, C., Douglass, J., Hyman, S.E., 1995. Neuronal adaptation to amphetamine and dopamine: molecular mechanisms of prodynorphin gene regulation in rat striatum. Neuron 14, 813-823.

Cunha-Oliveira, T., Rego, A.C., Cardoso, S.M., Borges, F., Swerdlow, R.H., Macedo, T., de Oliveira, C.R., 2006a. Mitochondrial dysfunction and caspase activation in rat cortical neurons treated with cocaine or amphetamine. Brain Res. 1089, 44-54.

Cunha-Oliveira, T., Rego, A.C., Morgadinho, M.T., Macedo, T., Oliveira, C.R., 2006b. Chronic effects of heroin and hydrogen peroxide in PC12 cells. Coimbra Médica, V series 2, 21-29.

Cunha-Oliveira, T., Rego, A.C., Morgadinho, M.T., Macedo, T., Oliveira, C.R., 2006c. Differential cytotoxic responses of PC12 cells chronically exposed to psychostimulants or to hydrogen peroxide. Toxicology 217, 54-62.

Cunha-Oliveira, T., Rego, A.C., Garrido, J., Borges, F., Macedo, T., Oliveira, C.R., 2007. Street heroin induces mitochondrial dysfunction and apoptosis in rat cortical neurons. J. Neurochem. 101, 543-554.

Davies, K.J., 1999. The broad spectrum of responses to oxidants in proliferating cells: a new paradigm for oxidative stress. IUBMB Life 48, 41-47.

Derlet, R.W., Albertson, T.E., Rice, P., 1990. Antagonism of cocaine, amphetamine, and methamphetamine toxicity. Pharmacol. Biochem. Behav. 36, 745-749.

Dey, S., Mactutus, C.F., Booze, R.M., Snow, D.M., 2007. Cocaine exposure in vitro induces apoptosis in fetal locus coeruleus neurons by altering the $\mathrm{Bax} / \mathrm{Bcl}-2$ ratio and through caspase- 3 apoptotic signaling. Neuroscience 144, 509-521.

Di Chiara, G., Tanda, G., Bassareo, V., Pontieri, F., Acquas, E., Fenu, S., Cadoni, C., Carboni, E., 1999. Drug addiction as a disorder of associative learning. Role of nucleus accumbens shell/ extended amygdala dopamine. Ann. N. Y. Acad. Sci. 877, 461-485.

Dietrich, J.B., Mangeol, A., Revel, M.O., Burgun, C., Aunis, D., Zwiller, J., 2005. Acute or repeated cocaine administration generates reactive oxygen species and induces antioxidant enzyme activity in dopaminergic rat brain structures. Neuropharmacology 48, 965-974.
Domingues, A., Cunha-Oliveira, T., Laco, M.L., Macedo, T.R., Oliveira, C.R., Rego, A.C., 2006. Expression of NR1/NR2B $\mathrm{N}$-methyl-D-aspartate receptors enhances heroin toxicity in HEK293 cells. Ann. N. Y. Acad. Sci. 1074, 458-465.

Eisch, A.J., Barrot, M., Schad, C.A., Self, D.W., Nestler, E.J., 2000. Opiates inhibit neurogenesis in the adult rat hippocampus. Proc. Natl. Acad. Sci. U. S. A. 97, 7579-7584.

Eisch, A.J., Harburg, G.C., 2006. Opiates, psychostimulants, and adult hippocampal neurogenesis: insights for addiction and stem cell biology. Hippocampus 16, 271-286.

Ellison, G., Eison, M.S., Huberman, H.S., Daniel, F., 1978. Long-term changes in dopaminergic innervation of caudate nucleus after continuous amphetamine administration. Science 201, 276-278.

Erinoff, L., 1995. General considerations in assessing neurotoxicity using neuroanatomical methods. Neurochem. Int. 26, 111-114.

Ersche, K.D., Clark, L., London, M., Robbins, T.W., Sahakian, B.J., 2006. Profile of executive and memory function associated with amphetamine and opiate dependence. Neuropsychopharmacology 31, 1036-1047.

European Monitoring Centre for Drugs and Drug Addiction, 2007. 2007 Annual Report on the State of the Drugs Problem in Europe.

Fecho, K., Lysle, D.T., 2000. Heroin-induced alterations in leukocyte numbers and apoptosis in the rat spleen. Cell. Immunol. 202, 113-123.

Fitzmaurice, P.S., Tong, J., Yazdanpanah, M., Liu, P.P., Kalasinsky, K.S., Kish, S.J., 2006. Levels of 4-hydroxynonenal and malondialdehyde are increased in brain of human chronic users of methamphetamine. J. Pharmacol. Exp. Ther. 319, 703-709.

Fleckenstein, A.E., Volz, T.J., Riddle, E.L., Gibb, J.W., Hanson, G.R., 2007. New insights into the mechanism of action of amphetamines. Annu. Rev. Pharmacol. Toxicol. 47, 681-698.

Frenzilli, G., Ferrucci, M., Giorgi, F.S., Blandini, F., Nigro, M., Ruggieri, S., Murri, L., Paparelli, A., Fornai, F., 2007. DNA fragmentation and oxidative stress in the hippocampal formation: a bridge between 3,4-methylenedioxymethamphetamine (ecstasy) intake and long-lasting behavioral alterations. Behav. Pharmacol. 18, 471-481.

Frey, B.N., Valvassori, S.S., Gomes, K.M., Martins, M.R., Dal-Pizzol, F., Kapczinski, F., Quevedo, J., 2006a. Increased oxidative stress in submitochondrial particles after chronic amphetamine exposure. Brain Res. 1097, 224-229.

Frey, B.N., Valvassori, S.S., Reus, G.Z., Martins, M.R., Petronilho, F.C., Bardini, K., Dal-Pizzol, F., Kapczinski, F., Quevedo, J., 2006b. Changes in antioxidant defense enzymes after D-amphetamine exposure: implications as an animal model of mania. Neurochem. Res. 31, 699-703.

Gage, F.H., 2002. Neurogenesis in the adult brain. J. Neurosci. 22, 612-613.

Garrido, J.M., Marques, M.P., Silva, A.M., Macedo, T.R., Oliveira-Brett, A.M., Borges, F., 2007. Spectroscopic and electrochemical studies of cocaine-opioid interactions. Anal. Bioanal. Chem. 388, 1799-1808.

Gatley, S.J., Gifford, A.N., Volkow, N.D., Fowler, J.S., 1998. Pharmacology of cocaine. In: Tarter (Ed.), Handbook of Substance Abuse: Neurobehavioral Pharmacology. Plenum Press, New York, pp. 161-185.

Gerfen, C.R., 1984. The neostriatal mosaic: compartmentalization of corticostriatal input and striatonigral output systems. Nature 311, 461-464.

Gesi, M., Ferrucci, M., Giusiani, M., Lenzi, P., Lazzeri, G., Alessandri, M.G., Salvadorini, A., Fulceri, F., Pellegrini, A., Fornai, F., Paparelli, A., 2004. Loud noise enhances nigrostriatal dopamine toxicity induced by MDMA in mice. Microsc. Res. Tech. 64, 297-303.

Gibb, J.W., Kogan, F.J., 1979. Influence of dopamine synthesis on methamphetamine-induced changes in striatal and adrenal tyrosine hydroxylase activity. Naunyn Schmiedebergs Arch. Pharmacol. 310, 185-187. 
Goldstein, R.Z., Volkow, N.D., 2002. Drug addiction and its underlying neurobiological basis: neuroimaging evidence for the involvement of the frontal cortex. Am. J. Psychiatry 159, 1642-1652.

Graham, D.G., Tiffany, S.M., Bell Jr., W.R., Gutknecht, W.F., 1978. Autoxidation versus covalent binding of quinones as the mechanism of toxicity of dopamine, 6-hydroxydopamine, and related compounds toward C1300 neuroblastoma cells in vitro. Mol. Pharmacol. 14, 644-653.

Green, A.R., Mechan, A.O., Elliott, J.M., O’Shea, E., Colado, M.I., 2003. The pharmacology and clinical pharmacology of 3,4-methylenedioxymethamphetamine (MDMA, "ecstasy"). Pharmacol. Rev. 55, 463-508.

Guzman, D.C., Vazquez, I.E., Brizuela, N.O., Alvarez, R.G., Mejia, G.B., Garcia, E.H., Santamaria, D., de Apreza, M.R., Olguin, H.J., 2006. Assessment of oxidative damage induced by acute doses of morphine sulfate in postnatal and adult rat brain. Neurochem. Res. 31, 549-554.

Hastings, T.G., Lewis, D.A., Zigmond, M.J., 1996. Role of oxidation in the neurotoxic effects of intrastriatal dopamine injections. Proc. Natl. Acad. Sci. U. S. A. 93, 1956-1961.

Hu, S., Sheng, W.S., Lokensgard, J.R., Peterson, P.K., 2002. Morphine induces apoptosis of human microglia and neurons. Neuropharmacology 42, 829-836.

Huber, J.D., Darling, S.F., Park, K.K., Soliman, K.F., 2001. The role of NMDA receptors in neonatal cocaine-induced neurotoxicity. Pharmacol. Biochem. Behav. 69, 451-459.

Hyman, S.E., Malenka, R.C., Nestler, E.J., 2006. Neural mechanisms of addiction: the role of reward-related learning and memory. Annu. Rev. Neurosci. 29, 565-598.

Iacovelli, L., Fulceri, F., De, B.A., Nicoletti, F., Ruggieri, S., Fornai, F., 2006. The neurotoxicity of amphetamines: bridging drugs of abuse and neurodegenerative disorders. Exp. Neurol. 201, 24-31.

Imam, S.Z., Duhart, H.M., Skinner, J.T., Ali, S.F., 2005. Cocaine induces a differential dose-dependent alteration in the expression profile of immediate early genes, transcription factors, and caspases in PC12 cells: a possible mechanism of neurotoxic damage in cocaine addiction. Ann. N. Y. Acad. Sci. 1053, 482-490.

Imam, S.Z., Itzhak, Y., Cadet, J.L., Islam, F., Slikker Jr., W., Ali, S.F., 2001. Methamphetamine-induced alteration in striatal p53 and bcl-2 expressions in mice. Brain Res. Mol. Brain Res. 91, 174-178.

Jackson, G.R., Sampath, D., Werrbach-Perez, K., Perez-Polo, J.R., 1994. Effects of nerve growth factor on catalase and glutathione peroxidase in a hydrogen peroxide-resistant pheochromocytoma subclone. Brain Res. 634, 69-76.

Jang, J.H., Surh, Y.J., 2004. Possible role of NF-kappaB in Bcl-X(L) protection against hydrogen peroxide-induced PC12 cell death. Redox. Rep. 9, 343-348.

Jatlow, P., McCance, E.F., Bradberry, C.W., Elsworth, J.D., Taylor, J.R., Roth, R.H., 1996. Alcohol plus cocaine: the whole is more than the sum of its parts. Ther. Drug. Monit. 18, 460-464.

Jayanthi, S., Ladenheim, B., Andrews, A.M., Cadet, J.L., 1999. Overexpression of human copper/zinc superoxide dismutase in transgenic mice attenuates oxidative stress caused by methylenedioxymethamphetamine (ecstasy). Neuroscience 91, 1379-1387.

Jenkins, A.J., Cone, E.J., 1998. Pharmacokinetics: drug absorption, distribution, and elimination. In: Karch, S.B. (Ed.), Drug Abuse Handbook. CRC Press LLC, pp. 165-215.

Jimenez, A., Jorda, E.G., Verdaguer, E., Pubill, D., Sureda, F.X., Canudas, A.M., Escubedo, E., Camarasa, J., Camins, A., Pallas, M., 2004. Neurotoxicity of amphetamine derivatives is mediated by caspase pathway activation in rat cerebellar granule cells. Toxicol. Appl. Pharmacol. 196, 223-234.

Johnson, E.A., O'Callaghan, J.P., Miller, D.B., 2004. Brain concentrations of D-MDMA are increased after stress. Psychopharmacology (Berl) 173, 278-286.
Jones, S.R., Joseph, J.D., Barak, L.S., Caron, M.G., Wightman, R.M., 1999. Dopamine neuronal transport kinetics and effects of amphetamine. J. Neurochem. 73, 2406-2414.

Jones, D.C., Gunasekar, P.G., Borowitz, J.L., Isom, G.E., 2000. Dopamine-induced apoptosis is mediated by oxidative stress and Is enhanced by cyanide in differentiated PC12 cells. J. Neurochem. 74, 2296-2304.

Kahlig, K.M., Binda, F., Khoshbouei, H., Blakely, R.D., McMahon, D.G., Javitch, J.A., Galli, A., 2005. Amphetamine induces dopamine efflux through a dopamine transporter channel. Proc. Natl. Acad. Sci. U. S. A. 102, 3495-3500.

Kalivas, P.W., Duffy, P., 1998. Repeated cocaine administration alters extracellular glutamate in the ventral tegmental area. J. Neurochem. 70, 1497-1502.

Kato, H., Narita, M., Suzuki, M., Yoshimoto, K., Yasuhara, M., Suzuki, T., 2007. Role of tyrosine kinase-dependent phosphorylation of NR2B subunit-containing NMDA receptor in morphine reward. Nihon Arukoru Yakubutsu Igakkai Zasshi 42, 13-20.

Koppel, B.S., Samkoff, L., Daras, M., 1996. Relation of cocaine use to seizures and epilepsy. Epilepsia 37, 875-878.

Krasnova, I.N., Ladenheim, B., Cadet, J.L., 2005. Amphetamine induces apoptosis of medium spiny striatal projection neurons via the mitochondria-dependent pathway. FASEB J. 19, 851-853.

Kreek, M.J., Laforge, K.S., Butelman, E., 2002. Pharmacotherapy of addictions. Nat. Rev. Drug Discov. 1, 710-726.

Kroemer, G., Martin, S.J., 2005. Caspase-independent cell death. Nat. Med. 11, 725-730.

Kuczenski, R., 1975. Effects of catecholamine releasing agents on synaptosomal dopamine biosynthesis: multiple pools of dopamine or multiple forms of tyrosine hydroxylase. Neuropharmacology 14, 1-10.

Langendorf, F.G., Anderson, D.C., Tupper, D.E., Rottenberg, D.A., Weisman, I.D., 1996. Brain atrophy and chronic cocaine abuse: background and work in progress. NIDA Res. Monogr. 163, $27-42$.

Leshner, A.I., 1997. Addiction is a brain disease, and it matters. Science 278, 45-47.

Li, M.O., Sarkisian, M.R., Mehal, W.Z., Rakic, P., Flavell, R.A., 2003. Phosphatidylserine receptor is required for clearance of apoptotic cells. Science 302, 1560-1563.

Lim, G., Wang, S., Lim, J.A., Mao, J., 2005. Activity of adenylyl cyclase and protein kinase A contributes to morphine-induced spinal apoptosis. Neurosci Lett. 389, 104-108.

Lipton, J.W., Gyawali, S., Borys, E.D., Koprich, J.B., Ptaszny, M., McGuire, S.O., 2003. Prenatal cocaine administration increases glutathione and alpha-tocopherol oxidation in fetal rat brain. Brain Res. Dev. Brain Res. 147, 77-84.

Liu, X.Y., Chu, X.P., Mao, L.M., Wang, M., Lan, H.X., Li, M.H., Zhang, G.C., Parelkar, N.K., Fibuch, E.E., Haines, M., Neve, K.A., Liu, F., Xiong, Z.G., Wang, J.Q., 2006. Modulation of D2R-NR2B interactions in response to cocaine. Neuron 52, 897-909.

Logan, B.J., Laverty, R., Sanderson, W.D., Yee, Y.B., 1988. Differences between rats and mice in MDMA (methylenedioxymethylamphetamine) neurotoxicity. Eur. J. Pharmacol. 152, 227-234.

Lyoo, I.K., Streeter, C.C., Ahn, K.H., Lee, H.K., Pollack, M.H., Silveri, M.M., Nassar, L., Levin, J.M., Sarid-Segal, O., Ciraulo, D.A., Renshaw, P.F., Kaufman, M.J., 2004. White matter hyperintensities in subjects with cocaine and opiate dependence and healthy comparison subjects. Psychiatry Res. 131, 135-145.

Ma, Y.Y., Guo, C.Y., Yu, P., Lee, D.Y., Han, J.S., Cui, C.L., 2006. The role of NR2B containing NMDA receptor in place preference conditioned with morphine and natural reinforcers in rats. Exp. Neurol. 200, 343-355.

Ma, Y.Y., Chu, N.N., Guo, C.Y., Han, J.S., Cui, C.L., 2007. NR2B-containing NMDA receptor is required for morphine-but not stress-induced reinstatement. Exp. Neurol. 203, 309-319. 
Macedo, D.S., de Vasconcelos, S.M., dos Santos, R.S., Aguiar, L.M., Lima, V.T., Viana, G.S., de Sousa, F.C., 2005. Cocaine alters catalase activity in prefrontal cortex and striatum of mice. Neurosci. Lett. 387, 53-56.

Mackowiak, M., Markowicz-Kula, K., Fijal, K., Wedzony, K., 2005. Acute and repeated administration of cocaine differentially regulates expression of PSA-NCAM-positive neurons in the rat hippocampus. Brain Res. 1055, 149-155.

Majewska, M.D., 1996. Cocaine addiction as a neurological disorder: implications for treatment. NIDA Res. Monogr. 163, 1-26.

Mao, J., Sung, B., Ji, R.R., Lim, G., 2002. Neuronal apoptosis associated with morphine tolerance: evidence for an opioid-induced neurotoxic mechanism. J. Neurosci. 22, 7650-7661.

Martin, G., Guadano-Ferraz, A., Morte, B., Ahmed, S., Koob, G.F., De, L.L., Siggins, G.R., 2004. Chronic morphine treatment alters $\mathrm{N}$-methyl-D-aspartate receptors in freshly isolated neurons from nucleus accumbens. J. Pharmacol. Exp. Ther. 311, 265-273.

McLaughlin, B.A., Nelson, D., Erecinska, M., Chesselet, M.F., 1998. Toxicity of dopamine to striatal neurons in vitro and potentiation of cell death by a mitochondrial inhibitor. J. Neurochem. 70, 2406-2415.

Milhazes, N., Cunha-Oliveira, T., Martins, P., Garrido, J., Oliveira, C., Rego, A.C., Borges, F., 2006. Synthesis and cytotoxic profile of 3,4-methylenedioxymethamphetamine ("ecstasy") and its metabolites on undifferentiated PC12 cells: a putative structure-toxicity relationship. Chem. Res. Toxicol. 19, 1294-1304.

Mirecki, A., Fitzmaurice, P., Ang, L., Kalasinsky, K.S., Peretti, F.J., Aiken, S.S., Wickham, D.J., Sherwin, A., Nobrega, J.N., Forman, H.J., Kish, S.J., 2004. Brain antioxidant systems in human methamphetamine users. J. Neurochem. 89, 1396-1408.

Mitchell, E.S., Snyder-Keller, A., 2003. c-fos and cleaved caspase-3 expression after perinatal exposure to ethanol, cocaine, or the combination of both drugs. Brain Res. Dev. Brain Res. 147, 107-117.

Murray, F., Harrison, N.J., Grimwood, S., Bristow, L.J., Hutson, P.H., 2007. Nucleus accumbens NMDA receptor subunit expression and function is enhanced in morphine-dependent rats. Eur. J. Pharmacol. 562, 191-197.

Naqvi, N.H., Rudrauf, D., Damasio, H., Bechara, A., 2007. Damage to the insula disrupts addiction to cigarette smoking. Science 315 , 531-534.

Nash, J.F., Roth, B.L., Brodkin, J.D., Nichols, D.E., Gudelsky, G.A., 1994. Effect of the $\mathrm{R}(-)$ and $\mathrm{S}(+)$ isomers of MDA and MDMA on phosphatidyl inositol turnover in cultured cells expressing 5-HT2A or 5-HT2C receptors. Neurosci. Lett. 177, 111-115.

Nassogne, M.C., Louahed, J., Evrard, P., Courtoy, P.J., 1997. Cocaine induces apoptosis in cortical neurons of fetal mice. J. Neurochem. 68, 2442-2450.

Nassogne, M.C., Evrard, P., Courtoy, P.J., 1998. Selective direct toxicity of cocaine on fetal mouse neurons. Teratogenic implications of neurite and apoptotic neuronal loss. Ann. N. Y. Acad. Sci. 846, 51-68.

Nestler, E.J., 2004b. Historical review: molecular and cellular mechanisms of opiate and cocaine addiction. Trends Pharmacol. Sci. 25, 210-218.

Nestler, E.J., 2004a. Molecular mechanisms of drug addiction. Neuropharmacology 47 (Suppl 1), 24-32.

Nixon, K., Crews, F.T., 2004. Temporally specific burst in cell proliferation increases hippocampal neurogenesis in protracted abstinence from alcohol. J. Neurosci. 24, 9714-9722.

Office of National Drug Control Policy, 2004. The Economic Costs of Drug Abuse in the United States 1992-2002. 20503: Office of the National Drug Control Policy, Washington, D.C.

Oliveira, M.T., Rego, A.C., Macedo, T.R., Oliveira, C.R., 2003. Drugs of abuse induce apoptotic features in PC12 cells. Ann. N. Y. Acad. Sci. 1010, 667-670.

Oliveira, M.T., Rego, A.C., Morgadinho, M.T., Macedo, T.R., Oliveira, C.R., 2002. Toxic effects of opioid and stimulant drugs on undifferentiated PC12 cells. Ann. N. Y. Acad. Sci. 965, 487-496.
Olsen, G.D., 1995. Potential mechanisms of cocaine-induced developmental neurotoxicity: a minireview. Neurotoxicology 16, 159-167.

Ozmen, I., Naziroglu, M., Alici, H.A., Sahin, F., Cengiz, M., Eren, I., 2007. Spinal morphine administration reduces the fatty acid contents in spinal cord and brain by increasing oxidative stress. Neurochem. Res. 32, 19-25.

Pau, C.W.H., Lee, T.M.C., Chan, S.F.F., 2002. The impact of heroin on frontal executive functions. Arch. Clin. Neuropsychol. 17, 663-670.

Pearson, J., Baden, M.B., Richter, R.W., 1976. Neuronal depletion in the globus pallidus of heroin addicts. Drug Alcohol Depend. 1, 349-356.

Pereira, F.C., Santos, S.D., Ribeiro, C.F., Ali, S.F., Macedo, T.R., 2004. A single exposure to morphine induces long-lasting hyporeactivity of rat caudate putamen dopaminergic nerve terminals. Ann. N. Y. Acad. Sci. 1025, 414-423.

Pereira, F.C., Lourenco, E., Milhazes, N., Morgadinho, T., Ribeiro, C.F., Ali, S.F., Macedo, T.R., 2006a. Methamphetamine, morphine, and their combination: acute changes in striatal dopaminergic transmission evaluated by microdialysis in awake rats. Ann. N. Y. Acad. Sci. 1074, 160-173.

Pereira, F.C., Lourenco, E.S., Borges, F., Morgadinho, T., Ribeiro, C.F., Macedo, T.R., Ali, S.F., 2006b. Single or multiple injections of methamphetamine increased dopamine turnover but did not decrease tyrosine hydroxylase levels or cleave caspase- 3 in caudate-putamen. Synapse 60, 185-193.

Poon, H.F., Abdullah, L., Mullan, M.A., Mullan, M.J., Crawford, F.C., 2007. Cocaine-induced oxidative stress precedes cell death in human neuronal progenitor cells. Neurochem. Int. 50, 69-73.

Pubill, D., Chipana, C., Camins, A., Pallas, M., Camarasa, J., Escubedo, E., 2005. Free radical production induced by methamphetamine in rat striatal synaptosomes. Toxicol. Appl. Pharmacol. 204, 57-68.

Qiusheng, Z., Yuntao, Z., Rongliang, Z., Dean, G., Changling, L., 2005. Effects of verbascoside and luteolin on oxidative damage in brain of heroin treated mice. Pharmazie 60, 539-543.

Ramsay, R.R., Hunter, D.J., 2002. Inhibitors alter the spectrum and redox properties of monoamine oxidase A. Biochim. Biophys. Acta 1601, 178-184.

Rego, A.C., Oliveira, C.R., 2003. Mitochondrial dysfunction and reactive oxygen species in excitotoxicity and apoptosis: implications for the pathogenesis of neurodegenerative diseases. Neurochem. Res. 28, 1563-1574.

Reid, M.S., Hsu Jr., K., Berger, S.P., 1997. Cocaine and amphetamine preferentially stimulate glutamate release in the limbic system: studies on the involvement of dopamine. Synapse 27, 95-105.

Rhodes, J.S., Crabbe, J.C., 2005. Gene expression induced by drugs of abuse. Curr. Opin. Pharmacol. 5, 26-33.

Ribeiro Do Couto, B., Aguilar, M.A., Manzanedo, C., Rodriguez-Arias, M., Minarro, J., 2004. Effects of NMDA receptor antagonists (MK-801 and memantine) on the acquisition of morphine-induced conditioned place preference in mice. Prog. Neuropsychopharmacol. Biol. Psychiatry 28, 1035-1043.

Riddle, E.L., Topham, M.K., Haycock, J.W., Hanson, G.R., Fleckenstein, A.E., 2002. Differential trafficking of the vesicular monoamine transporter- 2 by methamphetamine and cocaine. Eur. J. Pharmacol. 449, 71-74.

Ritz, M.C., Lamb, R.J., Goldberg, S.R., Kuhar, M.J., 1987. Cocaine receptors on dopamine transporters are related to self-administration of cocaine. Science 237, 1219-1223.

Rogers, R.D., Robbins, T.W., 2001. Investigating the neurocognitive deficits associated with chronic drug misuse. Curr. Opin. Neurobiol. 11, 250-257.

Rose, J.S., Branchey, M., Buydens-Branch, Stapleton, J.M., Chasten, K., Werrell, A., Maayan, M.L., 1996. Cerebral perfusion in early and late opiate withdrawal: a technetium-99m-HMPAO SPECT study. Psychiatry Res. 67, 39-47.

Rothman, R.B., Baumann, M.H., 2003. Monoamine transporters and psychostimulant drugs. Eur. J. Pharmacol. 479, 23-40. 
Sawynok, J., 1986. The therapeutic use of heroin: a review of the pharmacological literature. Can. J. Physiol. Pharmacol. 64, 1-6.

Scheggi, S., Mangiavacchi, S., Masi, F., Gambarana, C., Tagliamonte, A., De Montis, M.G., 2002. Dizocilpine infusion has a different effect in the development of morphine and cocaine sensitization: behavioral and neurochemical aspects. Neuroscience 109, 267-274.

Schilstrom, B., Yaka, R., Argilli, E., Suvarna, N., Schumann, J., Chen, B.T., Carman, M., Singh, V., Mailliard, W.S., Ron, D., Bonci, A., 2006. Cocaine enhances NMDA receptor-mediated currents in ventral tegmental area cells via dopamine D5 receptor-dependent redistribution of NMDA receptors. J. Neurosci. 26, 8549-8558.

Schmidt, C.J., Ritter, J.K., Sonsalla, P.K., Hanson, G.R., Gibb, J.W., 1985. Role of dopamine in the neurotoxic effects of methamphetamine. J. Pharmacol. Exp. Ther. 233, 539-544.

Shankaran, M., Yamamoto, B.K., Gudelsky, G.A., 2001. Ascorbic acid prevents 3,4-methylenedioxymethamphetamine (MDMA)-induced hydroxyl radical formation and the behavioral and neurochemical consequences of the depletion of brain 5-HT. Synapse 40, 55-64.

Shankaran, M., Yamamoto, B.K., Gudelsky, G.A., 1999. Involvement of the serotonin transporter in the formation of hydroxyl radicals induced by 3,4-methylenedioxymethamphetamine. Eur. J. Pharmacol. 385, 103-110.

Shoblock, J.R., Sullivan, E.B., Maisonneuve, I.M., Glick, S.D., 2003. Neurochemical and behavioral differences between $\mathrm{D}$-methamphetamine and $\mathrm{D}$-amphetamine in rats. Psychopharmacology (Berl) 165, 359-369.

Siggins, G.R., Martin, G., Roberto, M., Nie, Z., Madamba, S., De, L.L., 2003. Glutamatergic transmission in opiate and alcohol dependence. Ann. N. Y. Acad. Sci. 1003, 196-211.

Sitte, H.H., Huck, S., Reither, H., Boehm, S., Singer, E.A., Pifl, C., 1998. Carrier-mediated release, transport rates, and charge transfer induced by amphetamine, tyramine, and dopamine in mammalian cells transfected with the human dopamine transporter. J. Neurochem. 71, 1289-1297.

Sonsalla, P.K., 1995. The role of N-methyl-D-aspartate receptors in dopaminergic neuropathology produced by the amphetamines. Drug Alcohol Depend. 37, 101-105.

Sonsalla, P.K., Nicklas, W.J., Heikkila, R.E., 1989. Role for excitatory amino acids in methamphetamine-induced nigrostriatal dopaminergic toxicity. Science $243,398-400$.

Sprague, J.E., Nichols, D.E., 1995. The monoamine oxidase-B inhibitor L-deprenyl protects against 3,4-methylenedioxymethamphetamine-induced lipid peroxidation and long-term serotonergic deficits. J. Pharmacol. Exp. Ther. 273, 667-673.

Stumm, G., Schlegel, J., Schafer, T., Wurz, C., Mennel, H.D., Krieg, J.C., Vedder, H., 1999. Amphetamines induce apoptosis and regulation of bcl-x splice variants in neocortical neurons. FASEB J. 13, 1065-1072.

Sulzer, D., Chen, T.K., Lau, Y.Y., Kristensen, H., Rayport, S., Ewing, A., 1995. Amphetamine redistributes dopamine from synaptic vesicles to the cytosol and promotes reverse transport. J. Neurosci. 15, 4102-4108.

Sulzer, D., Sonders, M.S., Poulsen, N.W., Galli, A., 2005. Mechanisms of neurotransmitter release by amphetamines: a review. Prog. Neurobiol. 75, 406-433.

Teuchert-Noodt, G., Dawirs, R.R., Hildebrandt, K., 2000. Adult treatment with methamphetamine transiently decreases dentate granule cell proliferation in the gerbil hippocampus. J. Neural Transm. 107, 133-143.

Tramullas, M., Martinez-Cue, C., Hurle, M.A., 2008. Chronic administration of heroin to mice produces up-regulation of brain apoptosis-related proteins and impairs spatial learning and memory. Neuropharmacology 54, 640-652.

Trujillo, K.A., 2000. Are NMDA receptors involved in opiate-induced neural and behavioral plasticity? A review of preclinical studies. Psychopharmacology (Berl) 151, 121-141.
Tzschentke, T.M., Schmidt, W.J., 1995. N-methyl-D-aspartic acid-receptor antagonists block morphine-induced conditioned place preference in rats. Neurosci. Lett. 193, 37-40.

Tzschentke, T.M., Schmidt, W.J., 2003. Glutamatergic mechanisms in addiction. Mol. Psychiatry 8, 373-382.

Uhl, G.R., Grow, R.W., 2004. The burden of complex genetics in brain disorders. Arch. Gen. Psychiatry 61, 223-229.

United Nations Office on Drugs and Crime, 2007. World Drug Report 2007. United Nations Office on Drugs and Crime.

Volkow, N.D., Li, T.K., 2005. Drugs and alcohol: treating and preventing abuse, addiction and their medical consequences. Pharmacol. Ther. 108, 3-17.

Volkow, N.D., Fowler, J.S., Wang, G.J., 2003. The addicted human brain: insights from imaging studies. J. Clin. Invest. 111, 1444-1451.

Volkow, N.D., Fowler, J.S., Wang, G.J., Swanson, J.M., 2004. Dopamine in drug abuse and addiction: results from imaging studies and treatment implications. Mol. Psychiatry 9, 557-569.

Warren, M.W., Larner, S.F., Kobeissy, F.H., Brezing, C.A., Jeung, J.A., Hayes, R.L., Gold, M.S., Wang, K.K., 2007. Calpain and caspase proteolytic markers co-localize with rat cortical neurons after exposure to methamphetamine and MDMA. Acta Neuropathol. 114, 277-286.

Wiese, A.G., Pacifici, R.E., Davies, K.J., 1995. Transient adaptation of oxidative stress in mammalian cells. Arch. Biochem. Biophys. 318, 231-240.

Williams, J.M., Steketee, J.D., 2004. Cocaine increases medial prefrontal cortical glutamate overflow in cocaine-sensitized rats: a time course study. Eur. J. Neurosci. 20, 1639-1646.

Wolf, M.E., 1998. The role of excitatory amino acids in behavioral sensitization to psychomotor stimulants. Prog. Neurobiol. 54, 679-720.

Wolf, M.E., Xue, C.J., 1999. Amphetamine-induced glutamate efflux in the rat ventral tegmental area is prevented by MK-801, SCH 23390, and ibotenic acid lesions of the prefrontal cortex. J. Neurochem. 73, 1529-1538.

Wolf, S.L., Mikhael, M.A., 1979. Computerized transaxial tomographic and neuropsychol evaluations in chronic alcoholics and heroin abusers. Am. J. Psychiatry 136, 598-602.

Wu, C.W., Ping, Y.H., Yen, J.C., Chang, C.Y., Wang, S.F., Yeh, C.L., Chi, C.W., Lee, H.C., 2007. Enhanced oxidative stress and aberrant mitochondrial biogenesis in human neuroblastoma SH-SY5Y cells during methamphetamine induced apoptosis. Toxicol. Appl. Pharmacol. 220, 243-251.

Xi, Z.X., Stein, E.A., 2002. Blockade of ionotropic glutamatergic transmission in the ventral tegmental area reduces heroin reinforcement in rat. Psychopharmacology (Berl) 164, 144-150.

Xu, B., Wang, Z., Li, G., Li, B., Lin, H., Zheng, R., Zheng, Q., 2006. Heroin-administered mice involved in oxidative stress and exogenous antioxidant-alleviated withdrawal syndrome. Basic Clin. Pharmacol. Toxicol. 99, 153-161.

Yamaguchi, M., Suzuki, T., Abe, S., Hori, T., Kurita, H., Asada, T., Okado, N., Arai, H., 2002. Repeated cocaine administration differentially affects NMDA receptor subunit (NR1, NR2A-C) mRNAs in rat brain. Synapse 46, 157-169.

Yamaguchi, M., Suzuki, T., Seki, T., Namba, T., Juan, R., Arai, H., Hori, T., Asada, T., 2004. Repetitive cocaine administration decreases neurogenesis in adult rat hippocampus. Ann. N. Y. Acad. Sci. 1025, 351-362.

Yamamoto, B.K., Bankson, M.G., 2005. Amphetamine neurotoxicity: cause and consequence of oxidative stress. Crit. Rev. Neurobiol. 17, 87-117.

You, Z.B., Wang, B., Zitzman, D., Azari, S., Wise, R.A., 2007. A role for conditioned ventral tegmental glutamate release in cocaine seeking. J. Neurosci. 27, 10546-10555.

Zhu, J.P., Xu, W., Angulo, J.A., 2006. Methamphetamine-induced cell death: selective vulnerability in neuronal subpopulations of the striatum in mice. Neuroscience 140, 607-622. 